\title{
Observations of sesquiterpenes and their oxidation products in central Amazonia during the wet and dry seasons
}

Lindsay D. Yee ${ }^{1}$, Gabriel Isaacman-VanWertz ${ }^{1, a}$, Rebecca A. Wernis ${ }^{2}$, Meng Meng ${ }^{3, b}$, Ventura Rivera ${ }^{3}$, Nathan M. Kreisberg ${ }^{4}$, Susanne V. Hering ${ }^{4}$, Mads S. Bering ${ }^{5}$, Marianne Glasius ${ }^{5}$, Mary Alice Upshur ${ }^{6}$, Ariana Gray Bé ${ }^{6}$, Regan J. Thomson ${ }^{6}$, Franz M. Geiger ${ }^{6}$, John H. Offenberg ${ }^{7}$, Michael Lewandowski ${ }^{7}$, Ivan Kourtchev $^{8}$, Markus Kalberer ${ }^{8}$, Suzane de Sá9 ${ }^{9}$, Scot T. Martin ${ }^{9}, 10$, M. Lizabeth Alexander ${ }^{11}$, Brett B. Palm ${ }^{12}$, Weiwei Hu ${ }^{12}$, Pedro Campuzano-Jost ${ }^{12}$, Douglas A. Day ${ }^{12}$, Jose L. Jimenez ${ }^{12}$, Yingjun Liu ${ }^{9, c}$, Karena A. McKinney ${ }^{9, d}$, Paulo Artaxo $^{13}$, Juarez Viegas ${ }^{14}$, Antonio Manzi ${ }^{14}$, Maria B. Oliveira ${ }^{15}$, Rodrigo de Souza ${ }^{15}$, Luiz A. T. Machado ${ }^{16}$, Karla Longo ${ }^{17}$, and Allen H. Goldstein ${ }^{1}$

${ }^{1}$ Department of Environmental Science, Policy, and Management, University of California, Berkeley,

Berkeley, California 94720, USA

${ }^{2}$ Department of Civil and Environmental Engineering, University of California, Berkeley, Berkeley, California 94720, USA

${ }^{3}$ Department of Chemical Engineering, University of California, Berkeley, Berkeley, California 94720, USA

${ }^{4}$ Aerosol Dynamics Inc., Berkeley, California 94710, USA

${ }^{5}$ Department of Chemistry, Aarhus University, 8000 Aarhus C, Denmark

${ }^{6}$ Department of Chemistry, Northwestern University, Evanston, Illinois 60208, USA

${ }^{7}$ National Exposure Research Laboratory, Exposure Methods and Measurements Division, United States Environmental

Protection Agency, Research Triangle Park, North Carolina 27711, USA

${ }^{8}$ Department of Chemistry, University of Cambridge, Cambridge, CB2 1EW, UK

${ }^{9}$ School of Engineering and Applied Sciences, Harvard University, Cambridge, Massachusetts 02138, USA

${ }^{10}$ Department of Earth and Planetary Sciences, Harvard University, Cambridge, Massachusetts 02138, USA

${ }^{11}$ Environmental Molecular Sciences Laboratory, Pacific Northwest National Laboratory, Richland, Washington 99352, USA

${ }^{12}$ Dept. of Chemistry and Cooperative Institute for Research in Environmental Sciences (CIRES), University of Colorado,

Boulder, Colorado 80309, USA

${ }^{13}$ Department of Applied Physics, University of São Paulo, SP, Brazil

${ }^{14}$ Instituto Nacional de Pesquisas da Amazonia, Manaus, AM, Brazil

${ }^{15}$ Universidade do Estado do Amazonas, Manaus, AM, Brazil

${ }^{16}$ Instituto Nacional de Pesquisas Espiacais, São José dos Campos, SP, Brazil

${ }^{17}$ Instituto Nacional de Pesquisas Espiacais, Cachoeira Paulista, SP, Brazil

${ }^{a}$ now at: Department of Civil and Environmental Engineering, Virginia Tech, Blacksburg, Virginia 24061, USA

${ }^{b}$ now at: Department of Chemical Engineering and Applied Chemistry, University of Toronto, Toronto, CA, USA

${ }^{c}$ now at: Department of Environmental Science, Policy, and Management, University of California, Berkeley, Berkeley, California 94720, USA

${ }^{d}$ now at: Department of Chemistry, Colby College, Waterville, Maine 04901, USA

Correspondence: Lindsay D. Yee (lindsay.yee@ berkeley.edu)

Received: 20 February 2018 - Discussion started: 26 February 2018

Revised: 27 June 2018 - Accepted: 29 June 2018 - Published: 23 July 2018 
Abstract. Biogenic volatile organic compounds (BVOCs) from the Amazon forest region represent the largest source of organic carbon emissions to the atmosphere globally. These BVOC emissions dominantly consist of volatile and intermediate-volatility terpenoid compounds that undergo chemical transformations in the atmosphere to form oxygenated condensable gases and secondary organic aerosol (SOA). We collected quartz filter samples with $12 \mathrm{~h}$ time resolution and performed hourly in situ measurements with a semi-volatile thermal desorption aerosol gas chromatograph (SV-TAG) at a rural site ("T3") located to the west of the urban center of Manaus, Brazil as part of the Green Ocean Amazon (GoAmazon2014/5) field campaign to measure intermediate-volatility and semi-volatile BVOCs and their oxidation products during the wet and dry seasons. We speciated and quantified 30 sesquiterpenes and 4 diterpenes with mean concentrations in the range $0.01-6.04 \mathrm{ng} \mathrm{m}^{-3}$ (1$670 \mathrm{ppq}_{\mathrm{v}}$ ). We estimate that sesquiterpenes contribute approximately 14 and $12 \%$ to the total reactive loss of $\mathrm{O}_{3}$ via reaction with isoprene or terpenes during the wet and dry seasons, respectively. This is reduced from $\sim 50-70 \%$ for within-canopy reactive $\mathrm{O}_{3}$ loss attributed to the ozonolysis of highly reactive sesquiterpenes (e.g., $\beta$-caryophyllene) that are reacted away before reaching our measurement site. We further identify a suite of their oxidation products in the gas and particle phases and explore their role in biogenic SOA formation in the central Amazon region. Synthesized authentic standards were also used to quantify gas- and particle-phase oxidation products derived from $\beta$ caryophyllene. Using tracer-based scaling methods for these products, we roughly estimate that sesquiterpene oxidation contributes at least $0.4-5 \%$ (median $1 \%$ ) of total submicron OA mass. However, this is likely a low-end estimate, as evidence for additional unaccounted sesquiterpenes and their oxidation products clearly exists. By comparing our field data to laboratory-based sesquiterpene oxidation experiments we confirm that more than 40 additional observed compounds produced through sesquiterpene oxidation are present in Amazonian SOA, warranting further efforts towards more complete quantification.

\section{Introduction}

The emission of biogenic volatile organic compounds (BVOCs) from terrestrial vegetation represents a large source of organic carbon to Earth's atmosphere. These emissions comprise a wide array of chemical species, including known terpenoids: isoprene $\left(\mathrm{C}_{5}\right)$, monoterpenes $\left(\mathrm{C}_{10}\right)$, sesquiterpenes $\left(\mathrm{C}_{15}\right)$, and diterpenes $\left(\mathrm{C}_{20}\right)$. Isoprene, 2-methyl-1,3butadiene $\left(\mathrm{C}_{5} \mathrm{H}_{8}\right)$, is a hemi-terpene and the most dominant non-methane hydrocarbon emitted to the atmosphere at levels of $\sim 500 \mathrm{TgC} \mathrm{yr}^{-1}$ globally (Guenther et al., 2006, 2012). Global emissions of terpenes are estimated for monoter- penes $\left(\mathrm{C}_{10} \mathrm{H}_{16}\right)$ at $\sim 160 \mathrm{TgC} \mathrm{yr}^{-1}$, sesquiterpenes $\left(\mathrm{C}_{15} \mathrm{H}_{24}\right)$ at $\sim 30 \mathrm{Tg} \mathrm{yr}^{-1}$, and global emission estimates for diterpenes $\left(\mathrm{C}_{20} \mathrm{H}_{42}\right)$ have yet to be made (Guenther et al., 2012).

In the atmosphere, such compounds undergo chemical transformations that lead to the formation of biogenic secondary organic aerosol (BSOA) and affect local radical budgets (Kesselmeier et al., 2013; Lelieveld et al., 2008, 2016) and carbon cycling (Bouvier-Brown et al., 2012; Guenther, 2002). Globally, the majority of organic aerosols stem from the oxidation of biogenic carbon, yet their role in affecting Earth's radiative balance remains unclear (Committee on the Future of Atmospheric Chemistry Research et al., 2016). This is largely due to limited observations of the speciated precursors and identification of their oxidation products, which are crucial for understanding their chemical pathways and fate in Earth's atmosphere (Worton et al., 2012).

While laboratory measurements simulating the oxidation of BVOCs provide insight into atmospheric chemistry, challenges still exist for making ambient, high-time-resolution, speciated measurements of the higher-carbon-number terpenes and their oxidation. These compounds present measurement challenges for several reasons. First, their relatively low vapor pressure makes sample collection more challenging due to line losses. Second, they tend to be present at lower ambient concentrations due to lower emission and higher reactivity, therefore requiring very sensitive detection methods and/or lower time resolution. These measurement challenges have resulted in more research focused on highly volatile and higher-concentration BVOCs (i.e., isoprene, monoterpenes), but there is less understanding of sesquiterpenes (BouvierBrown et al., 2009a, b; Chan et al., 2016) and almost no data on concentrations or chemical reaction pathways of diterpenes.

Isoprene has a laboratory-determined SOA yield of $<6 \%$ (Dommen et al., 2006; King et al., 2010; Kroll et al., 2005, 2006; Xu et al., 2014) and an estimated $3.3 \%$ yield in the southeastern US (Marais et al., 2016), but nevertheless contributes a major fraction of organic aerosol over forested regions because it is emitted in such high quantities relative to other BVOCs (Carlton et al., 2009; Hu et al., 2015). Though other terpenes are present in the atmosphere at much lower concentrations, they generally react faster with oxidants such as $\mathrm{OH}, \mathrm{O}_{3}$, and $\mathrm{NO}_{3}$ (Atkinson, 1997) and have higher SOA yields at typical atmospheric OA concentrations: $\sim 5-10 \%$ for monoterpenes as reported in Griffin et al. (1999a, b) and $\sim 20-70 \%$ for sesquiterpenes as reported in Chen et al. (2012), Griffin et al. (1999b), Hoffmann et al. (1997), Jaoui et al. (2013), and Lee et al. (2006a, b). SOA yields from diterpenes have not yet been quantified, though they are likely higher than those of sesquiterpenes due to their higher carbon number and lower volatility. While emitted mass generally decreases with decreasing volatility (and increasing carbon number), the concomitant rise in the sheer possible number of compounds from $\mathrm{C}_{5}$ to $\mathrm{C}_{10}$ to $\mathrm{C}_{15}$ to $\mathrm{C}_{20}$ backbones and the associated SOA yields and oxidant reactivity 
indicates that lower-volatility terpenes may have an important impact on regional chemistry and BSOA formation.

Using the BVOC emission model, MEGAN2.1, it is predicted that $\sim 80 \%$ of terpenoid emissions come from tropical trees that cover about $20 \%$ of the global land surface (Guenther et al., 2012), yet very few observations of sesquiterpenes exist from these regions. Chemical characterization of tropical plant tissue shows the presence of an abundance of sesquiterpenes (F. Chen et al., 2009; Courtois et al., 2012) and suggests their widespread emission from such vegetation (F. Chen et al., 2009; Courtois et al., 2009). Previous branch enclosure measurements of native Amazon saplings found that sesquiterpene emission was below detection limits (Bracho-Nuñez et al., 2013) even though sesquiterpenes have been observed within and outside the canopy of the central Amazon (Alves et al., 2016; Jardine et al., 2012). Further, F. Chen et al. (2009) observed higher sesquiterpene emissions from wounded seedlings of the tropical tree $\mathrm{Co}$ paifera officinalis, with similar composition and quantity to that in the leaves. However, while ambient concentrations of sesquiterpenes have been measured by field-deployable mass spectrometers such as proton transfer time-of-flight mass spectrometry (Jordan et al., 2009), previous measurements have provided little or no separation of isomers, which can vary substantially (orders of magnitude) in their reactivity and SOA yields, so a significant knowledge gap remains regarding the contribution of these compounds to organic aerosol.

Aerosols play a critical role in cloud formation and the hydrologic cycle of the Brazilian Amazon (Fan et al., 2018; Pöschl et al., 2010; Wang et al., 2016), which is also one of the major source regions of global BVOCs. Previous studies have found the aerosols over this region (Martin et al., 2010) to be primarily composed of organic material (Artaxo et al., 2013) derived from BVOCs (Q. Chen et al., 2009, 2015). While isoprene oxidation has been estimated to contribute $\sim 50 \%$ of OA in Amazonia (Q. Chen et al., 2015), of which a large portion is attributed to the uptake of isoprene-epoxydiols (Hu et al., 2015; de Sá et al., 2017), the remaining contribution to OA from other BVOC precursors such as monoterpenes and sesquiterpenes remains largely unconstrained. Khan et al. (2017) report that including updated sesquiterpene emissions and SOA pathways (all represented by the $\beta$-caryophyllene mechanism) in the STOCHEM global chemical transport model led to a $48 \%$ increase in global SOA burden and $57 \%$ increase in SOA production rate. In addition, the highest concentrations of sesquiterpene-derived SOA were modeled to be present over central Africa and South America. However, the general lack of available time-resolved measurements of speciated sesquiterpenes and their oxidation products in either the gas or particle phase has precluded fully constraining their contribution to BSOA formation. For terpenes in general there are even greater measurement challenges associated with the observation of tracers of their oxidation: the gas-phase com- ponent of these semi-volatile compounds may condense in sample lines, be lost by wet or dry deposition, or quickly react to form compounds sufficiently ubiquitous to be disconnected from a specific precursor. Particle-phase composition is therefore critical for studying the importance of individual terpenes and terpene classes, but the dynamic gas-particle partitioning of these semi-volatile products requires the contemporaneous measurement of the difficult-to-measure gasphase components. Measurements of gas-particle partitioning and concentrations of biogenic OA tracers from isoprene and monoterpene oxidation have been reported previously as part of the Green Ocean Amazon (GoAmazon2014/5) field campaign (Isaacman-VanWertz et al., 2016), but few, if any, sesquiterpene oxidation products were identified in the dataset at that time. To fully characterize the sources of OA in the region, molecular-level and chemically specific signatures of oxidation products from a more complete range of BVOC precursors need to be identified and quantified.

Here we report the first speciated measurement of 30 sesquiterpenes and four diterpenes in the central Amazon and assess their role in reactive oxidant losses during the wet and dry seasons through in situ observations with a semi-volatile thermal desorption aerosol gas chromatograph (SV-TAG) and off-line measurements of quartz-filter-collected aerosol samples. We further report measurements of the specific oxidation products of the sesquiterpene $\beta$-caryophyllene that were synthesized in the laboratory and attribute more than 40 additional species observed on a representative filter sample from the wet season to sesquiterpene oxidation based on comparison to products found in laboratory-based oxidation experiments. Finally, we provide a rough low-end estimate of the contribution of sesquiterpene oxidation to $\mathrm{OA}$ in the region.

\section{Experimental section}

\subsection{Green Ocean Amazon (GoAmazon2014/5) field campaign: "T3" site description}

Measurements were conducted as part of the Green Ocean Amazon (GoAmazon2014/5) field campaign, for which the scientific objectives and measurement sites are described in an overview paper by Martin et al. (2016). We present observations from the wet and dry seasons of 2014, respectively referred to as intensive operating periods 1 and 2 (IOP1 and IOP2). Wet season measurements were taken 1 February to 31 March 2014 and dry season measurements were taken 15 August to 15 October 2014 at the "T3" Manacapuru rural site, located $70 \mathrm{~km}$ downwind of urban Manaus. The T3 site was located on a cleared pasture site $\left(-3.2133,-60.5987^{\circ}\right)$ $2 \mathrm{~km}$ north of the nearest heavily traveled road, which connects Manaus to Manacapuru. The immediate surrounding forest ( $\sim 1 \mathrm{~km}$ away) consisted primarily of secondary forest, and the prevailing meteorological conditions (northeast- 
erly winds) resulted in the regional transport of clean air from the primary forest north and east of the site mixed with the outflow of Manaus pollution from the east.

Several instruments for investigating gas- and particlephase chemistry were housed at $\mathrm{T} 3$ alongside the instrument suite of the United States Department of Energy Atmospheric Radiation Measurement (ARM) Climate Research Facility. ARM trailers consisted of the Atmospheric Radiation Measurement Facility One (AMF-1) and Mobile Aerosol Observing System (MAOS; Mather and Voyles, 2013). Here we focus on measurements conducted using a semi-volatile thermal desorption aerosol gas chromatograph (SV-TAG) and quartz filters collected using a custom-designed sequential filter sampler.

\subsection{Deployment of a semi-volatile thermal desorption aerosol gas chromatograph (SV-TAG)}

We deployed a semi-volatile thermal desorption aerosol gas chromatograph (SV-TAG) housed in one of the instrument trailers at T3. Details of the instrument development and operation have been published previously (Isaacman-VanWertz et al., 2016; Isaacman et al., 2014; Kreisberg et al., 2009; Williams et al., 2006; Zhao et al., 2013) and we describe SVTAG deployment briefly here. During the campaign, ambient air was pulled through a $15.24 \mathrm{~cm}$ ID duct at $\sim 5 \mathrm{~m}$ above ground level. Flow through the ducting was maintained at laminar flow conditions with minimal residence time to minimize loss of semi-volatile species from the center line of flow. Air was then subsampled from the center of the sampling duct at $20 \mathrm{~L} \mathrm{~min}^{-1}$ for $22 \mathrm{~min}$ through a cyclone $\left(\mathrm{PM}_{1}\right.$ cut point) to SV-TAG's dual collection cells held at $32^{\circ} \mathrm{C}$. Concentrations and gas-particle partitioning were measured through a combination of particle-only measurements, in which gas-phase components were removed through a series of two multichannel carbon monolith denuders (500 channels, $30 \mathrm{~mm}$ OD $\times 40.6 \mathrm{~cm}$; MAST Carbon) upstream of one collection cell, and total gas-plus-particle measurements with no removal of the gas-phase component. One collection cell always sampled total gas-plus-particle concentrations, while the other cell alternated between particle-only samples and total gas-plus-particle samples, which were used to remove any bias between collection cells. Particle fraction, $F_{\mathrm{p}}$, is calculated by comparing the particle-only signal from the denuded channel to the gas and particle signal from the other cell. Measurements of $F_{\mathrm{p}}$ for many tracers of biogenic origin from this campaign were presented previously in IsaacmanVanWertz et al. (2016) and an intercomparison of SV-TAG and other instrumentation for measuring $F_{\mathrm{p}}$ is described in Thompson et al. (2017). We found here that sesquiterpenes and their oxidation products detected by SV-TAG were completely in the gas phase ( $F_{\mathrm{p}}$ was zero, as discussed in Sect. 3.1 and 3.2.3), so we do not present time-dependent $F_{\mathrm{p}}$ measurements for these compounds. As described in IsaacmannVanWertz et al. (2016), regular checks of denuder efficiency were done by inserting a filter upstream of the denuder to remove particles and sampling the normal volume of air through this "blank" system so the measured signal would indicate any breakthrough. Any remaining mass signal was subtracted from the sample mass signal as part of data correction before quantification. Previous laboratory testing of the denuder efficiency was also performed by sending gas standards (e.g., the sesquiterpene longifolene) through the denuder and measuring the sesquiterpene signal upstream and downstream using proton-transfer-reaction mass spectrometry. This led to a calculated penetration value on average of $<5 \%$ for a single denuder and a predicted penetration of $<0.5 \%$ for the two denuders used in series on SV-TAG.

After sample collection, material was thermally desorbed from the collection cells into helium $(\mathrm{He})$ at a rate of $35^{\circ} \mathrm{C} \mathrm{min}^{-1}$ up to $320^{\circ} \mathrm{C}$, taking approximately $8 \mathrm{~min}$. The helium was saturated with a derivatization agent, $\mathrm{N}$-methyl$\mathrm{N}$-(trimethylsilyl) trifluoroacetamide (MSTFA), which converts polar $-\mathrm{OH}$ moieties to $-\mathrm{OSi}\left(\mathrm{CH}_{3}\right)_{3}$ (trimethylsilyl ester) groups for separation on a gas chromatography column (Isaacman et al., 2014). Desorbed material was focused onto a pre-concentrator held at $30^{\circ} \mathrm{C}$ and then transferred onto a gas chromatography column (Restek, Rtx-5Sil MS; $20 \mathrm{~m} \times 0.18 \mathrm{~mm} \times 0.18 \mu \mathrm{m}$ ) via a valveless injector (Kreisberg et al., 2014). Analysis was performed using an Agilent 7890A/5975 gas chromatograph (GC) coupled to a quadrupole mass spectrometer (MS). The GC program consisted of He flow at $1 \mathrm{sccm}$ and a ramp from 50 to $330^{\circ} \mathrm{C}$ (ramp rate $23.6^{\circ} \mathrm{C} \mathrm{min}^{-1}$ ), then holding at $330^{\circ} \mathrm{C}$ for $2.2 \mathrm{~min}$ while He flow ramped to $3 \mathrm{sccm}$. The use of online derivatization greatly extends the use of SV-TAG for analysis of the highly oxygenated species typical of BVOC oxidation, but it also renders more complex chromatograms. For many of the observed sesquiterpenes, their individual contributions to the total ion signal within a chromatogram were low. Thus, analysis was occasionally performed ( $\sim$ every $13 \mathrm{~h}$ ) without derivatization to allow for clearer identification and quantification of all detected sesquiterpene species. To generate continuous time series of the total sesquiterpene concentration as presented in Sect. 3.2.1, we assumed that the longerlived and regularly detected $\alpha$-copaene comprised $6 \%$ of total sesquiterpene concentration at all times, since this was the average $\%$ composition during runs without derivatization (Fig. S1 in the Supplement).

\subsubsection{Compound identification}

A typical sample total ion chromatogram (TIC) contains hundreds to thousands of compounds. For peak deconvolution, compound peaks are separated and quantified using a characteristic ("selected") ion fragment. Chemical identification is aided by comparing the peak's background-subtracted mass spectrum and $n$-alkane-based retention index to those of authentic standards run on SV-TAG or presented in the literature and available mass spectral libraries. The 2014 


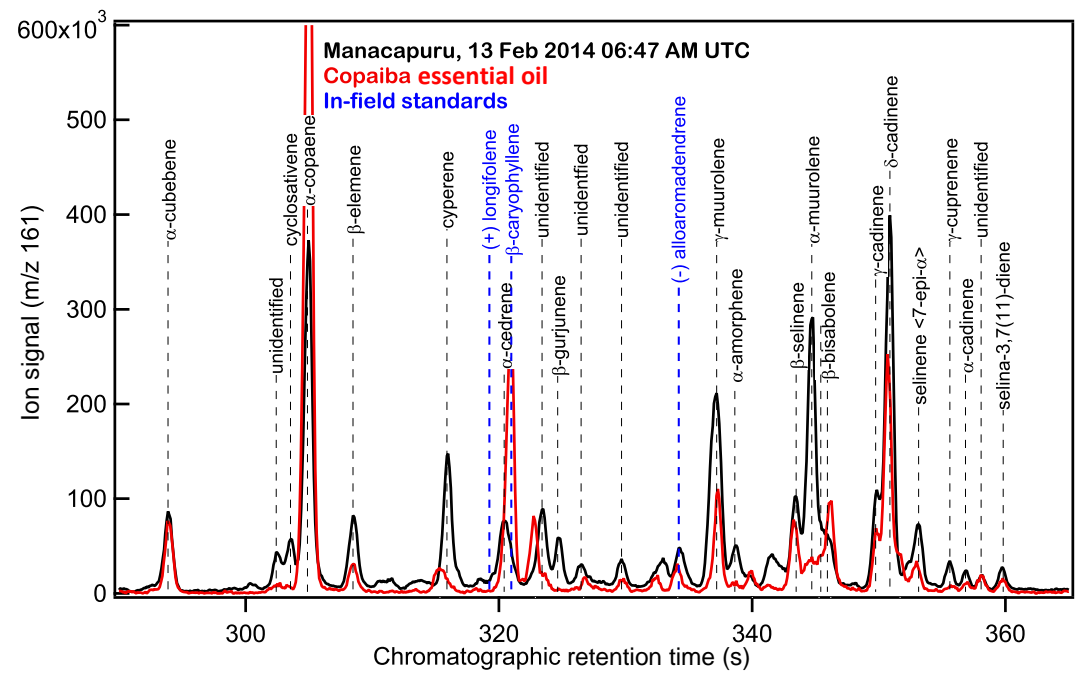

Figure 1. Selected ion chromatograms at sesquiterpene characteristic ion $m / z .161$ of ambient air (black) and copaiba essential oil (red). Sesquiterpenes in ambient air were measured in the gas phase. Copaiba essential oil was analyzed from direct liquid injection on SV-TAG collection cells. Retention times for standards analyzed in the field are indicated in blue.

NIST/EPA/NIH Mass Spectral Library (Stein et al., 2014), the Adams essential oil library (Adams, 2007), and a proprietary library from a flavor and fragrance company (MANE) were used for mass spectral matching. A match factor is calculated from a comparison function outlined in Stein (1994) as a measure of the overall probability that an obtained spectral match is correct. Spectral matches are considered perfect if the match factor (Stein, 1994) is 999, excellent if $>900$, good if 800-900, and fair if 700-800. Further, additional work using electron impact (EI) mass spectral matching to identify components of a complex OA sample found that the probability of incorrect identification was low (30 and 14\%) for match factors between 800-900 and $>900$, respectively (Worton et al., 2017). Here we present proposed identities if the spectral match factor is $>800$ and the retention index is reasonable with the proposed identity. Retention index (RI) is helpful for determining the elution order of compounds and narrowing the possible compound identities for species such as the sesquiterpenes with similar mass spectra. We calculate the $n$-alkane-based retention index for compound $i$ using Eq. (1) below:

$\mathrm{RI}=100 \times\left[n+\frac{t_{i}-t_{n}}{t_{n+1}-t_{i}}\right]$,

where $n$ is the number of carbon atoms of the $n$-alkane that elutes before species $i$, and $t$ represents retention time.

Sesquiterpenes with the chemical formula $\mathrm{C}_{15} \mathrm{H}_{24}$ were mostly resolved within single ion chromatograms (Fig. 1) by a characteristic ion, $m / z 161, \mathrm{C}_{12} \mathrm{H}_{17}^{+}$, typically coincident with the molecular ion, $m / z$ 204. In addition, a few sesquiterpenoids with the chemical formula $\mathrm{C}_{15} \mathrm{H}_{22}$ were resolved at their molecular ion $(m / z 202)$, and a few diterpenes with the chemical formula $\mathrm{C}_{20} \mathrm{H}_{32}$ were resolved using the character- istic ion, $m / z$ 257. In some cases, peak signal was too low to provide good mass spectra (MS) matching, so retention index information was also used to propose identities.

While many sesquiterpenes observed in ambient chromatograms are not available as authentic standards, sesquiterpene-rich essential oils from Amazonian trees were injected on SV-TAG for chromatographic separation and to aid in identification. These included copaiba essential oil and andiroba essential oil obtained from a local pharmacy in Manacapuru, Brazil and additional bottles of copaiba essential oil obtained from Young Living Essential Oils, Lehi, UT and through personal communication (origin Bolivia). Copaiba essential oil originates from trees of the genus $\mathrm{Co}$ paifera, comprising over 70 species (Plowden, 2003), several of which are distributed throughout the greater Amazon region (Xiloteca Calvino Mainieri et al., 2018) While copaiba trees are commonly referred to as the "diesel" or "kerosene" tree due to the oil's limited use as a biofuel, the essential oil is extracted primarily for medicinal purposes. Andiroba essential oil is derived from Carapa guianensis, also widely used for medicinal purposes.

While the exact composition, grade, and quality of the essential oils depends on multiple factors (e.g., extraction method, species, origin), we hypothesized that the essential oils may serve as a proxy for emissions of terpenes within the canopy and that the ambient sesquiterpene composition might reflect a similar composition to the essential oils. Studies have previously observed the chemical similarity between that of terpene emissions and within-plant content (Ormeño et al., 2010), specifically for Copaifera officinalis (F. Chen et al., 2009). Most of the sesquiterpenes observed in ambient samples (13 February 2014 06:47 UTC, 02:47 LT) coincide with those observed in copaiba essential oil (Fig. 1, black and 
red traces, respectively). This similarity between the ambient sesquiterpene composition and essential oil composition also allowed for positive identification of some of the peaks in the ambient chromatogram. Sesquiterpene standards that were commonly available and brought to the field as standards included (+)-longifolene, $\beta$-caryophyllene, and alloaromadendrene with their chromatographic retention times indicated in Fig. 1. Further, the essential oils injected on SV-TAG have relatively similar sesquiterpene composition (Table $\mathrm{S} 3$ in the Supplement) and are comparable to previously analyzed essential oils and tissue from Amazonian trees (Table S4).

\subsubsection{Compound quantification}

In-field calibrations on SV-TAG were performed using an auto liquid injection system (Isaacman et al., 2011) to deliver customized standard solutions. A calibration point was obtained every 6-7 h, rendering a complete six-point calibration curve within $48 \mathrm{~h}$. Within a selected ion chromatogram (SIC), peak signal is integrated at the quantification ion and calibrated based on the best available authentic standard. The peak-integrated ion signal of both the analyte and the standard is normalized by the integrated ion signal of an isotopically labeled internal standard in each sample to account for differences in recovery by compound functionality in SV-TAG as well as changing MS detector response over time. For the sesquiterpenes, n-tetradecane $\mathrm{d}_{30}$ (CAS no. 204244-81-5) was selected as the internal standard to normalize by. Reported oxidation products are normalized using 2- $\mathrm{C}^{13}$-pentaerythritol. Compounds were quantified using authentic standards whenever possible, though analyticalgrade standards for many of the observed sesquiterpenes are not commercially available and/or were not present in the custom standard solution that was used for in-field calibrations. Longifolene, $\beta$-caryophyllene, and alloaromadendrene were the only sesquiterpenes present in the calibration solution during deployment, and only $\beta$-caryophyllene and alloaromadendrene were occasionally detected in ambient air. Post-deployment calibrations were performed in the laboratory with newly acquired sesquiterpene standards using relative response factors to $\beta$-caryophyllene. A range of instrument responses to sesquiterpene standards was observed. For example, on-column lower detection limits were $0.14,0.01,0.05$, and $0.08 \mathrm{ng}$ with precisions of 14,21 , 9.5 , and $13 \%$ and accuracies of $12,7.4,25$, and $17 \%$, for $\beta$-caryophyllene, longifolene, alloaromadendrene, and $\alpha$ copaene, respectively. An average response factor for several sesquiterpenes was used to quantify compounds for which authentic standards were not available (Chan et al., 2016). All sesquiterpenes are quantified on $m / z=161$; the average sensitivity of most sesquiterpenes to quantification on this ion is $6.4 \pm 6.0$ times more sensitive than for $\beta$ caryophyllene. The calculated on-column lower detection limit is $0.07 \mathrm{ng}$ with typical precision of the order of $14 \%$ and accuracy errors within $30 \%$. Additional details of er- ror analysis for SV-TAG data are presented in Isaacman et al. (2014).

Standards of several oxidation products from $\beta$ caryophyllene ozonolysis were custom synthesized at Northwestern University. The oxidation products synthesized were $\beta$-caryophyllene aldehyde, $\beta$-nocaryophyllone aldehyde, $\beta$-caryophyllonic acid, $\beta$-nocaryophyllonic acid, $\beta$-caryophyllinic acid, and $\beta$-nocaryophyllinic acid. Synthesis details and procedures are outlined in Gray Bé et al. (2017). Each standard was analyzed in the laboratory by SV-TAG and by two-dimensional gas chromatography with high-resolution time-of-flight mass spectrometry $(\mathrm{GC} \times \mathrm{GC}-\mathrm{HR}-\mathrm{ToF}-\mathrm{MS})$ to obtain MS and retention time information to aid the identification of these compounds in sample chromatograms. Relative response factors of the synthesized standards to pinonic acid, a compound in the regular standard solution for SV-TAG during deployment, were obtained and used for quantification.

\subsubsection{Laboratory-generated SOA from sesquiterpenes}

Filter samples from laboratory oxidation experiments of several sesquiterpenes were analyzed by $\mathrm{GC} \times \mathrm{GC}-\mathrm{HR}-\mathrm{ToF}-\mathrm{MS}$ to provide mass spectral information for the identification of potential sesquiterpene-derived oxidation products in ambient samples. Mass spectra of resolved peaks from these and previously analyzed filters were added to custom MS libraries and are listed in Table S1. Sesquiterpenes were oxidized in the U.S. EPA National Exposure Research Laboratory reactors (Table S2) in the dark via ozonolysis; some were also oxidized under conditions of $\mathrm{OH}$ oxidation in the presence of $\mathrm{NO}_{x}$ according to methods described previously (Jaoui et al., 2003, 2004, 2013, 2016; Offenberg et al., 2017). The following sesquiterpene systems were studied: $\beta$-caryophyllene, $\alpha$-cedrene, $\alpha$-copaene, aromadendrene, $\beta$ farnasene, and $\alpha$-humulene. In addition, a complex mixture rich in sesquiterpenes (copaiba essential oil, Amazon origin) was also oxidized under ozonolysis conditions as a representation of the potential mixture expected in the Amazon atmosphere.

\subsection{Supporting measurements}

Several supporting measurements were made that allow for interpretation of the chemistry observed. These include gasphase measurements of BVOCs from a proton transfer timeof-flight mass spectrometer (PTR-ToF-MS; Ionicon Analytik) and particle-phase measurements from an Aerodyne high-resolution aerosol mass spectrometer (HR-ToF-AMS), hereinafter referred to as the AMS (DeCarlo et al., 2006). Operation and analysis procedures are outlined elsewhere for the PTR-ToF-MS (Liu et al., 2016) and for the AMS (de Sá et al., 2017). Positive matrix factorization analysis of AMS data was performed to resolve the statistical factor, isoprene epoxydiol-SOA (IEPOX-SOA), which is considered to be a 
tracer for organic aerosol formed through the particle uptake of isoprene epoxydiols and has been previously described (de Sá et al., 2017). Filter-based measurements were also taken using a custom-built sequential filter sampler. Selected filter samples were analyzed using various chromatographic, ionization, and mass spectrometric techniques to provide additional chemical insight. The sequential filter sampler and filter analysis techniques are described briefly in the following sections. Routine meteorology data and gas-phase measurements (e.g., $\mathrm{O}_{3}$ ) were provided by the Atmospheric Radiation Measurement (ARM) Climate Research Facility, a U.S. Department of Energy Office of Science user facility sponsored by the Office of Biological and Environmental Research.

\subsubsection{Sequential filter sampler}

Aerosol samples were collected on quartz-fiber filters using a custom-built sequential filter sampler (Aerosol Dynamics, Inc.). Ambient air was sampled at $120 \mathrm{Lmin}^{-1}$ through a $2.4 \mathrm{~cm}$ ID stainless steel tube $4 \mathrm{~m}$ above ground level. Sampled air passed through $2.7 \mathrm{~m}$ of $2 \mathrm{~cm}$ ID copper tubing kept at temperatures below the dew point of the trailer temperature for trapping excess water with periodic manual removal. The sample inlet geometry and flow conditions minimized particle losses $(<5 \%)$ for those between 10 and $1000 \mathrm{~nm}$. We estimate $70 \%$ removal of intermediate-volatility organic compounds (IVOCs), minimizing adsorption of gas-phase organics onto the filters. Previous filter measurements have noted sampling artifacts due to $\mathrm{O}_{3}$ penetration (Dzepina et al., 2007). We estimate $90 \%$ removal of $\mathrm{O}_{3}$ (estimated diffusive losses) for the sampler design used in this study, which should minimize the further reaction of organics collected on filters.

Following the water removal stage was a pair of greaseless cyclones operating in parallel with aerodynamic diameter cut points of $1 \mu \mathrm{m}$. The cyclones are equivalent to the AIHL cyclone (John and Reischl, 1980) originally designed for $\mathrm{PM}_{2.5}$ collection at $21.7 \mathrm{~L} \mathrm{~min}^{-1}$ but experimentally verified to provide $\mathrm{PM}_{1}$ separation at $60 \mathrm{~L} \mathrm{~min}^{-1}$. The sample was then introduced into a $91 \mathrm{~cm}$ length of $32 \mathrm{~mm}$ ID aluminium tubing to one of six filter housings (HiQ, ILPH-102) containing a $101.6 \mathrm{~mm}$ diameter quartz-fiber filter (Whatman, QMA Quartz). Filter housings were modified from the manufacturer to remove all adhesives to prevent potential off-gas and contamination of the filter samples. Further modifications to the housings included replacing filter supports with custometched $316 \mathrm{~L}$ stainless steel support screens and utilizing an O-ring face seal not in contact with the sample flow or filter.

Before deployment filters were pre-treated by baking at $550{ }^{\circ} \mathrm{C}$ for $12 \mathrm{~h}$. During IOP1 (wet season), samples were collected at approximately $12 \mathrm{~h}$ time resolution from 06:1518:00 and 18:30-06:15 local time (LT). Filter changes occurred daily from 18:00-18:30 LT. Field blanks were also collected weekly in each filter holder. Filter samples collected during IOP2 (dry season) are not presented in this analysis as the wet season filters were more ideal for targeted isolation and detection of sesquiterpene oxidation products. Similarly targeted samples from the dry season had a similar chemical composition in terms of terpene oxidation as that presented in Sect. 3.3 for the wet season, so this presentation is not repeated, though there are certainly contributions from additional OA sources (e.g., biomass burning compounds are more prominent in the dry than wet season). A more complete analysis of all samples from both seasons will be presented in a separate forthcoming publication. The goal in the current analysis is to simply demonstrate the number and chemical complexity of the observed sesquiterpenederived compounds and the potential for their significance in contributing to overall OA mass. Filter samples were kept frozen (or transported on ice) until analysis. Switching valves were automated to time sample collection appropriately over each filter throughout the day. Flow rates were logged in LabVIEW using a TSI mass flow meter (model 4045).

\subsubsection{Two-dimensional gas chromatography with high-resolution time-of-flight mass spectrometry (GC x GC-HR-ToF-MS)}

Selected filter samples and standards were analyzed in the laboratory using two-dimensional gas chromatography with high-resolution time-of-flight mass spectrometry. Aliquots of samples (multiples of ovoid filter punches with an area of $0.4 \mathrm{~cm}^{2}$ each) were introduced into the gas chromatograph using a thermal-desorption autosampler (Gerstel, TDS-3 and TDSA2) with built-in derivatization using MSTFA. Compounds were separated first on a nonpolar column (Restek, Rxi-5Sil-MS, $60 \mathrm{~m} \times 0.25 \mathrm{~mm} \times 250 \mu \mathrm{m})$, then transferred to a Zoex Corporation cryogenic dual-stage thermal modulator comprised of guard column (Restek, $1.5 \mathrm{~m} \times 0.25 \mathrm{~mm}$, Siltek). The modulation period was $2.3 \mathrm{~s}$, followed by separation on a secondary column (Restek, Rtx-200MS, $1 \mathrm{~m} \times 0.25 \mathrm{~mm} \times 250 \mu \mathrm{m})$ to separate polar compounds. The GC temperature program ramped from 40 to $320^{\circ} \mathrm{C}$ at a rate of $3.5^{\circ} \mathrm{C} \mathrm{min}-1$, holding for $5 \mathrm{~min}$, and the He carrier gas flow was $2 \mathrm{~mL} \mathrm{~min}^{-1}$. Following chromatographic separation, analysis was performed with a Tofwerk high-resolution $\left(\frac{m}{\Delta m} \approx 4000\right)$ mass spectrometer employing electron impact $(70 \mathrm{eV})$ ionization.

To correct for compound transmission efficiency through the system, total ion signal for each peak was corrected based on a volatility curve comprising even-carbon-numbered perdeuterated alkanes as internal standards (from $\mathrm{C}_{12} \mathrm{D}_{26}$ through $\left.\mathrm{C}_{36} \mathrm{D}_{74}\right)$. The custom-synthesized $\beta$-caryophyllene oxidation products (described in Sect. 2.2.2) and several filter samples containing sesquiterpene-derived SOA from laboratory oxidation experiments (described in Sect. 2.2.3) were analyzed to create characteristic mass spectra of sesquiterpene-derived oxidation products. These mass spectra were put into custom MS libraries and added to the available NIST 14 MS libraries within NIST MS Search 
v.2.2 software to be searched against when analyzing sample chromatograms. Custom MS libraries comprising the mass spectra of products from previous laboratory oxidation experiments of the monoterpenes $\alpha$-pinene, myrcene, and dlimonene were also included in MS searches. These custom MS libraries are available online for the use of the atmospheric chemistry community as indicated in the "Data availability" section and are the subject of a future publication. Published MS in the literature was also used to identify previously reported tracers of isoprene and terpene oxidation as described in Sect. 3.3.2. For peaks with "good" MS match factors $>800$ out of 1000 (Stein, 1994) and an alkane-based retention index matching within \pm 10 of that of the library entry, a tentative match was considered, at least for source categorization of the peak. Some peaks with $<800$ MS match factors were included after manual review accounting for co-elutions and other factors affecting MS quality and MS matching.

\subsubsection{Ultrahigh-performance liquid chromatography mass spectrometry (UHPLC-MS)}

A subset of filters were extracted and analyzed using ultrahigh-performance liquid chromatography coupled to quadrupole time-of-flight MS (UHPLC-qToF-MS) for carboxylic acids and organosulfates. The method was based on Kristensen and Glasius (2011) and Kristensen et al. (2016). Monoterpene oxidation products were analyzed using these methods and further optimized for the analysis of sesquiterpene products. Filters were extracted in $1: 1$ methanol: acetonitrile assisted by sonication, evaporated to dryness using nitrogen gas, and reconstituted in $200 \mu \mathrm{L}$ MilliQ water with $10 \%$ acetonitrile and $0.1 \%$ acetic acid. The UHPLC system used an Acquity T3 column $(1.8 \mu \mathrm{m}$, $2.1 \times 100 \mathrm{~mm}$; Waters) with a mobile phase of eluent A: $0.1 \%$ acetic acid in MilliQ water and eluent B: acetonitrile with $0.1 \%$ acetic acid (eluent flow was $0.3 \mathrm{~mL} \mathrm{~min}^{-1}$ ). The 18 min gradient was eluent B increased from 3 to $80 \%$ from 1 to $12 \mathrm{~min}$ and then increased to $100 \%$ (during $0.5 \mathrm{~min}$ ) where it was held for $3 \mathrm{~min}$ before returning to initial conditions. The qToF-MS had an electrospray ionization source and was operated in negative ionization mode with a nebulizer pressure of $3.0 \mathrm{bar}$, dry gas flow of $7.0 \mathrm{~L} \mathrm{~min}^{-1}$, source voltage of $3.0 \mathrm{kV}$, and transfer time of $50 \mu \mathrm{s}$. Oxidation products of $\beta$-caryophyllene were identified by comparison of their mass spectra with previous work (Alfarra et al., 2012; Chan et al., 2011; van Eijck et al., 2013; Jaoui et al., 2003) and products obtained from a smog chamber study of the ozonolysis of $\beta$-caryophyllene. The quantification of $\beta$-caryophyllinic acid was performed using a synthesized standard provided by Jevgeni Parshintsev (Helsinki University) following previously reported synthesis procedures (Parshintsev et al., 2010), and the quantification of $\beta$-nocaryophyllonic acid was performed using the custom- synthesized standard at Northwestern University described in Gray Bé et al. (2017).

\subsubsection{Nanoelectrospray (nanoESI) ultrahigh-resolution mass spectrometry (UHRMS)}

Selected filter samples from the wet season were extracted and analyzed by a direct infusion ultrahigh-resolution LTQ Orbitrap Velos mass spectrometer (Thermo Fisher, Bremen, Germany) equipped with a TriVersa NanoMate robotic nanoflow chip-based electrospray ionization (nanoESI; Advion Biosciences, Ithaca NY, USA) source according to methods described previously (Kourtchev et al., 2013, 2014, $2015,2016)$. This analysis provided mass resolution power of $\geq 100000$ and mass accuracy $<1$ ppm to provide molecular assignments. The direct infusion nanoESI parameters were as follows: the ionization voltage and back pressure were set at $-1.4 \mathrm{kV}$ and $0.8 \mathrm{psi}$, respectively. The inlet temperature was $200^{\circ} \mathrm{C}$. The sample flow rate was approximately $200-300 \mathrm{~nL} \mathrm{~min}^{-1}$. The negative ionization mass spectra were collected in three replicates over ranges $m / z 100-650$ and $m / z$ 150-900 and processed using Xcalibur 2.1 software (Thermo Scientific). Chemical formulae of the form $\mathrm{C}_{\mathrm{c}} \mathrm{H}_{\mathrm{h}} \mathrm{N}_{\mathrm{n}} \mathrm{O}_{\mathrm{o}} \mathrm{S}_{\mathrm{s}}$ were made according to analysis procedures presented in Kourtchev et al. $(2013,2015)$ and Zielinski et al. (2018), and only ions that were observed in all three replicate extract analyses were kept for evaluation. All sample intensities were normalized to the aerosol organic carbon loading as well.

\section{Results and discussion}

\subsection{Chemical characterization of observed sesquiterpenes}

A total of 30 sesquiterpene species were observed regularly in the gas phase in SV-TAG chromatograms during the GoAmazon campaign at T3 (Fig. 1). Compound names for those compounds positively identified via MS matching and retention index are labeled accordingly in chromatograms and listed with mean concentrations observed during the wet and dry seasons in Table 1. Most sesquiterpene species were observed at mean levels above $100 \mathrm{ppq}_{\mathrm{v}}$, ranging $1-529 \mathrm{ppq}_{\mathrm{v}}$ in the wet season and $2-670 \mathrm{ppq}_{\mathrm{v}}$ in the dry season. While mean observed concentrations differed for some species observed in the wet and dry season, the overall summed mean concentrations of sesquiterpenes were similar in both seasons $\left(\sim 4-5 \mathrm{ppq}_{\mathrm{v}}\right)$.

Complete timelines of speciated sesquiterpenes are presented in Fig. 2 for the wet season and Fig. 3 for the dry season. In panel (a), six species are presented with hourly time resolution under regularly derivatized run conditions. In panel (b), occasional runs without derivatization allow for the complete speciation of sesquiterpene and diterpene species and the calculation of the summed concentration of 
Table 1. Sesquiterpenes and terpenoids observed in the gas phase during GoAmazon2014/5 with proposed identification and their alkanebased retention index, Chemical Abstracts Service (CAS) number, mean concentration during wet and dry seasons, reaction rate constant with $\mathrm{O}_{3}\left(k_{\mathrm{O}_{3}}\right)$, and estimated chemical lifetime in the presence of $20 \mathrm{ppb}_{\mathrm{v}} \mathrm{O}_{3} \cdot k_{\mathrm{O}_{3}}$ is estimated using EPA EPI Suite 4.1 AOPWIN where literature data are unavailable. Concentrations of each species are estimated by using an average instrument response factor for several sesquiterpene standards unless otherwise noted that an authentic standard was used. Other commonly studied sesquiterpenes typically below detection or unobserved are also included for comparison of reactive timescales.

\begin{tabular}{|c|c|c|c|c|c|c|c|c|c|}
\hline \multirow[t]{2}{*}{ No. } & \multirow[t]{2}{*}{ Compound } & \multirow[t]{2}{*}{$\begin{array}{r}\text { Retention } \\
\text { index }\end{array}$} & \multirow[t]{2}{*}{ CAS no. } & \multicolumn{2}{|c|}{$\begin{array}{c}\text { Wet season } \\
\text { mean } \\
\text { concentration }\end{array}$} & \multicolumn{2}{|c|}{$\begin{array}{c}\text { Dry season } \\
\text { mean } \\
\text { concentration }\end{array}$} & \multirow[t]{2}{*}{$\begin{array}{r}k_{\mathrm{O}_{3}} \times 10^{17} \\
\left(\mathrm{~cm}^{3} \mathrm{molec}^{-1}\right. \\
\left.\mathrm{s}^{-1}\right)\end{array}$} & \multirow[t]{2}{*}{$\begin{array}{r}\tau \text { for }\left[\mathrm{O}_{3}\right] \\
=20 \mathrm{ppb}_{\mathrm{V}} \\
(\mathrm{min})\end{array}$} \\
\hline & & & & $\left(\mathrm{ng} \mathrm{m}^{-3}\right)$ & $\left(\mathrm{ppq}_{\mathrm{v}}\right)$ & $\left(\mathrm{ng} \mathrm{m}^{-3}\right)$ & $\left(\mathrm{ppq}_{\mathrm{v}}\right)$ & & \\
\hline \multicolumn{10}{|c|}{ Sesquiterpenes } \\
\hline 1 & $\alpha$-cubebene & 1355 & $17699-14-8$ & 2.25 & 250 & 1.90 & 211 & 43.0 & 78.9 \\
\hline 2 & unidentified & 1380 & & 2.86 & 318 & 1.12 & 125 & & \\
\hline 3 & cyclosativene & 1383 & $22469-52-9$ & 2.86 & 317 & 1.16 & 129 & 7.4 & 458.7 \\
\hline 4 & $\alpha$-copaene & 1387 & $3856-25-5$ & $3.75^{\mathrm{a}}$ & 417 & $3.92^{\mathrm{a}}$ & 435 & $16^{\mathrm{b}}$ & 212.0 \\
\hline 5 & $\beta$-elemene & 1397 & $515-13-9$ & 2.08 & 231 & 1.46 & 163 & 2.6 & 1317.2 \\
\hline 6 & cyperene & 1420 & $2387-78-2$ & 1.61 & 179 & 0.81 & 90 & $\mathrm{NE}^{\mathrm{c}}$ & \\
\hline 7 & $\alpha$-cedrene & 1435 & $469-61-4$ & $0.25^{\mathrm{a}}$ & 28 & $0.45^{\mathrm{a}}$ & 49 & $2.8^{\mathrm{b}}$ & 78.9 \\
\hline 8 & unidentified & 1443 & & 4.76 & 529 & 6.04 & 670 & & \\
\hline 9 & $\beta$-gurjunene & 1447 & $17334-55-3$ & 0.88 & 97 & 0.88 & 98 & 7.4 & 458.7 \\
\hline 10 & unidentified & 1453 & $26620-71-3$ & 0.32 & 35 & 0.01 & 2 & & \\
\hline 11 & unidentified & 1462 & & 1.61 & 179 & 1.38 & 153 & & \\
\hline 12 & $\alpha$-patchoulene & 1471 & $560-32-7$ & 0.27 & 30 & 1.01 & 113 & 7.4 & 458.7 \\
\hline 13 & unidentified; SQT202 & 1474 & & 0.29 & 33 & 0.43 & 49 & & \\
\hline 14 & $(-)$ alloaromadendrene ${ }^{\mathrm{a}}$ & 1476 & $025246-27-9$ & $1.93^{\mathrm{a}}$ & 214 & $1.72^{\mathrm{a}}$ & 191 & 1.2 & 2826.4 \\
\hline 15 & $\gamma$-muurolene & 1486 & $30021-74-0$ & 0.18 & 20 & 0.11 & 12 & 44.2 & 76.7 \\
\hline 16 & unidentified; SQT202 & 1486 & & 2.36 & 265 & 4.89 & 548 & & \\
\hline 17 & $\alpha$-amorphene & 1490 & $20085-19-2$ & 1.23 & 136 & 1.03 & 114 & 86.0 & 39.4 \\
\hline 18 & $\beta$-selinene & 1505 & $17066-67-0$ & 0.45 & 50 & 2.38 & 264 & 2.4 & 1413.2 \\
\hline 19 & $\alpha$-muurolene & 1509 & $31983-22-9$ & 1.50 & 166 & 1.45 & 161 & 86.0 & 39.4 \\
\hline 20 & unidentified & 1512 & & 2.14 & 237 & 1.50 & 167 & & \\
\hline 21 & $\beta$-bisabolene & 1513 & $495-61-4$ & 1.24 & 138 & 0.32 & 36 & 87.20 & 38.9 \\
\hline 22 & cuparene & 1524 & $16982-00-6$ & 1.13 & 127 & 0.62 & 69 & & \\
\hline 23 & $\gamma$-cadinene & 1526 & $39029-41-9$ & 1.75 & 194 & 1.18 & 131 & 44.2 & 76.7 \\
\hline 24 & $\delta$-cadinene & 1529 & $483-76-1$ & 0.95 & 105 & 0.81 & 90 & 163.0 & 20.8 \\
\hline 25 & cis-calamenene SQT202 & 1534 & $72937-55-4$ & 0.81 & 91 & 0.32 & 35 & $\mathrm{NE}^{\mathrm{c}}$ & \\
\hline 26 & selinene $<7$-epi- $\alpha>$ & 1537 & $6813-21-4$ & 0.14 & 15 & 0.22 & 25 & 163.0 & 20.8 \\
\hline 27 & $\gamma$-cuprenene & 1545 & $4895-23-2$ & 0.32 & 35 & 0.14 & 15 & 50.4 & 67.3 \\
\hline 28 & $\alpha$-cadinene & 1549 & $24406-05-1$ & 0.17 & 18 & 0.06 & 7 & 86.0 & 39.4 \\
\hline 29 & unidentified & 1553 & & 0.01 & 1 & 0.13 & 14 & & \\
\hline 30 & selina-3,7(11)-diene & 1558 & $6813-21-4$ & 0.07 & 8 & 0.10 & 11 & 163.0 & 20.8 \\
\hline \multicolumn{10}{|c|}{ Below detection or unobserved } \\
\hline & $\beta$-caryophyllene & 1427 & $87-44-5$ & $\mathrm{n} / \mathrm{a}$ & $\mathrm{n} / \mathrm{a}$ & $\mathrm{n} / \mathrm{a}$ & $\mathrm{n} / \mathrm{a}$ & 1160.0 & 2.9 \\
\hline & trans- $\alpha$-bergamotene & 1442 & $13474-59-4$ & $\mathrm{n} / \mathrm{a}$ & $\mathrm{n} / \mathrm{a}$ & $\mathrm{n} / \mathrm{a}$ & $\mathrm{n} / \mathrm{a}$ & 86.0 & 39.4 \\
\hline & aromadendrene & 1450 & $489-39-4$ & $\mathrm{n} / \mathrm{a}$ & $\mathrm{n} / \mathrm{a}$ & $\mathrm{n} / \mathrm{a}$ & $\mathrm{n} / \mathrm{a}$ & 1.2 & 2826.4 \\
\hline & $\alpha$-humulene & 1471 & $6753-98-6$ & $\mathrm{n} / \mathrm{a}$ & $\mathrm{n} / \mathrm{a}$ & $\mathrm{n} / \mathrm{a}$ & $\mathrm{n} / \mathrm{a}$ & 1170.0 & 2.9 \\
\hline & $\beta$-farnesene & & $18794-84-8$ & $\mathrm{n} / \mathrm{a}$ & $\mathrm{n} / \mathrm{a}$ & $\mathrm{n} / \mathrm{a}$ & $\mathrm{n} / \mathrm{a}$ & $40.1^{\mathrm{d}}$ & 84.6 \\
\hline & $\alpha$-farnesene & 1509 & $502-61-4$ & $\mathrm{n} / \mathrm{a}$ & $\mathrm{n} / \mathrm{a}$ & $\mathrm{n} / \mathrm{a}$ & $\mathrm{n} / \mathrm{a}$ & 104.0 & 32.6 \\
\hline & valencene & 1523 & $4630-07-3$ & $\mathrm{n} / \mathrm{a}$ & $\mathrm{n} / \mathrm{a}$ & $\mathrm{n} / \mathrm{a}$ & $\mathrm{n} / \mathrm{a}$ & 8.6 & 394.7 \\
\hline \multicolumn{10}{|c|}{ Diterpenes } \\
\hline 31 & rimuene & 1958 & $1686-67-5$ & 0.21 & 18 & 0.22 & 19 & 7.6 & 448.1 \\
\hline 32 & pimaradiene & 1977 & $1686-61-9$ & 0.11 & 10 & 0.14 & 12 & 7.6 & 448.1 \\
\hline 33 & Sandaracopimaradiene & 1995 & $1686-56-2$ & 0.38 & 33 & 0.15 & 13 & 7.6 & 448.1 \\
\hline \multirow[t]{2}{*}{34} & kaurene & 2085 & $34424-57-2$ & 0.97 & 86 & 0.69 & 60 & 1.1 & 2981.7 \\
\hline & Total & esquiterpen & + diterpenes: & 41.8 & 4611 & 38.8 & 4285 & $\mathrm{n} / \mathrm{a}$ & $\mathrm{n} / \mathrm{a}$ \\
\hline
\end{tabular}

${ }^{a}$ Authentic standard used for quantification. ${ }^{b}$ Shu and Atkinson (1994). ${ }^{c}$ NE: no estimate in EPI Suite. ${ }^{d}$ Kourtchev et al. (2009). 


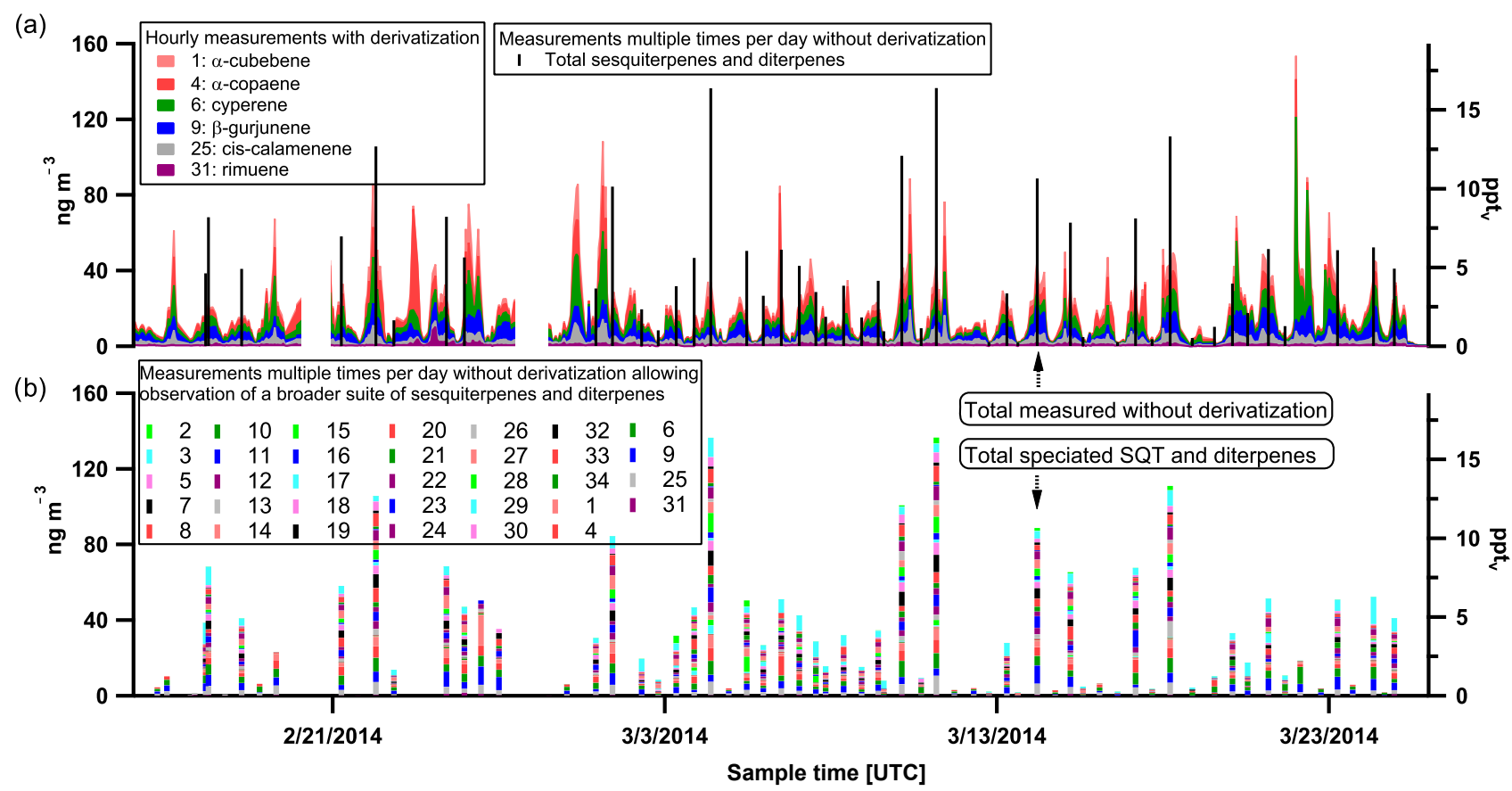

Figure 2. Wet season timeline of sesquiterpene (SQT) and diterpene species for those measured with hourly time resolution with derivatization (shaded colors) (a) and those measured multiple times per day at lower time resolution without derivatization (b). Legend entries correspond to compound numbers in Table 1. Total SQTs and diterpenes quantified during runs without derivatization are overlaid in black for reference in panel (a). Concurrent speciation shown in (b).

sesquiterpenes and diterpenes as overlaid in panel (a). For both seasons, sesquiterpenes exhibit highest concentrations overnight. Also note that a more dynamic range of summed sesquiterpene concentrations was observed during the wet season (spanning across $15 \mathrm{ppt}_{\mathrm{v}}$ ), whereas in the dry season the range is closer to $8 \mathrm{ppt}_{\mathrm{v}}$. Further, the wet season exhibits greater chemodiversity of observed sesquiterpenes and terpenes compared to the dry season.

\subsection{Sesquiterpene oxidation}

We further explore in this section indicators for sesquiterpene oxidation in the region. First, by comparing relative concentrations of isoprene, monoterpenes, and sesquiterpenes at T3 to those made within the canopy at an upwind Amazon forest site (Alves et al., 2016), we confirm that the majority of sesquiterpene oxidation must occur within or near the canopy. Second, differences in chemical composition between ambient samples at our site away from the canopy and that of sesquiterpene-rich essential oils (used as a proxy for emission profile within the canopy) reveals that the most reactive sesquiterpenes in the oils (e.g., $\beta$-caryophyllene) are reacted away to levels below detection by SV-TAG before reaching the sampling location at T3. Third, we observe known oxidation products of $\beta$-caryophyllene in SV-TAG and on filter samples collected at T3.

\subsubsection{Sesquiterpene contribution to total $\mathrm{O}_{3}$ reactivity}

Sesquiterpenes are observed at concentrations much lower than those of monoterpenes and isoprene (Figs. 4a and 5a). They generally react relatively quickly with $\mathrm{O}_{3}$, which dominates their reactive loss, and thus a strong anticorrelation with $\mathrm{O}_{3}$ concentration is observed (Figs. 4a and 5a). During daytime, the levels of photochemically produced $\mathrm{O}_{3}$ keep sesquiterpene concentrations low. In addition, the downward transport of ozone-rich air during convective storms in the Amazon that typically occur during late morning or early afternoon hours (Gerken et al., 2016) also contribute to the temporal concentration profile observed with highest concentrations at night (Fig. 6). This is in contrast with typically observed daytime maxima for isoprene and monoterpenes (Alves et al., 2016; Yáñez-Serrano et al., 2015), for which reactive loss is dominated by reaction with $\mathrm{OH}$ and with $\mathrm{OH} / \mathrm{O}_{3}$, respectively (Atkinson, 1997; Kesselmeier et al., 2013; Kesselmeier and Staudt, 1999), and whose daytime emissions are likely more associated with immediate release following production as a function of solar radiation input (Alves et al., 2014; Bracho-Nuñez et al., 2013; Harley et al., 2004; Jardine et al., 2015; Kuhn, 2002; Kuhn et al., 2004).

To better understand the reactive loss of $\mathrm{O}_{3}$, the estimated cumulative loss of $\mathrm{O}_{3}$ by reaction with sesquiterpenes compared to that by reaction with isoprene and monoterpenes is shown for the wet and dry seasons in Figs. $4 \mathrm{~b}$ and 5b, respec- 


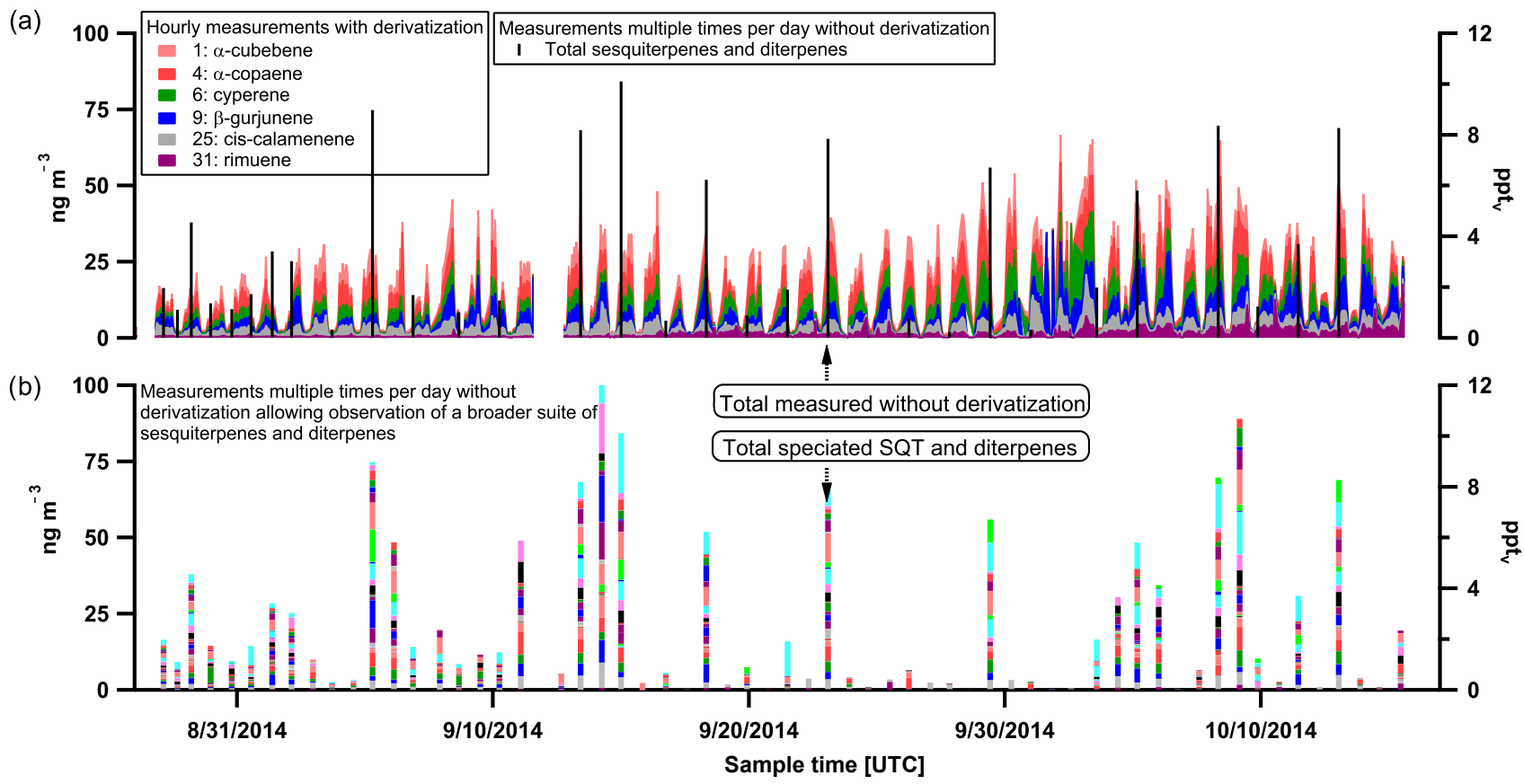

Figure 3. Dry season timeline of sesquiterpene (SQT) and diterpene species for those measured with hourly time resolution with derivatization (shaded colors) (a) and those measured multiple times per day at lower time resolution without derivatization (b). Legend entries correspond to compound numbers in Table 1 and colors in (b) are the same used in Fig. 1b. Total SQTs and diterpenes quantified during runs without derivatization are overlaid in black for reference in panel (a). Concurrent speciation shown in (b).

tively. $\mathrm{O}_{3}$ reactivity $\left(\mathrm{s}^{-1}\right)$ is defined as the summed product of each terpene concentration $\left(\right.$ molec $\mathrm{cm}^{-3}$ ) and its secondorder rate constant $\left(\mathrm{molec}^{-1} \mathrm{~cm}^{3} \mathrm{~s}^{-1}\right)$ for reaction with $\mathrm{O}_{3}$. Of the approximately 20 regularly observed sesquiterpenes by SV-TAG, only two species ( $\alpha$-copaene and $\alpha$-cedrene) have their reaction rate constants with all three major atmospheric oxidants $\left(\mathrm{O}_{3}, \mathrm{OH}\right.$, and $\left.\mathrm{NO}_{3}\right)$ measured in the laboratory (Atkinson and Arey, 2003; Shu and Atkinson, 1994). For the remaining sesquiterpenes, reaction rate constants were estimated using the Environmental Protection Agency's Estimation Program Interface Suite (U.S. EPA, 2000). Reaction rate constants (estimated and measured) are listed in Table 1 for the observed sesquiterpenes. Additional reaction rate constants for other sesquiterpenes that are commonly reported but unobserved in this study are provided for comparison. The estimated contribution to $\mathrm{O}_{3}$ reactivity from sesquiterpenes remains uncertain, as discrepancies of 1 to 2 orders of magnitude sometimes exist between measured and estimated reaction rate constants. For example, the estimated reaction rate constant for $\beta$-caryophyllene is $44.2 \times 10^{-17} \mathrm{~cm}^{3} \mathrm{molec}^{-1} \mathrm{~s}^{-1}$ and the experimentally determined rate is $1170 \times 10^{-17} \mathrm{~cm}^{3} \mathrm{molec}^{-1} \mathrm{~s}^{-1}$, leading to calculated lifetimes via ozonolysis at $20 \mathrm{ppb}_{\mathrm{v}} \mathrm{O}_{3}$ of 77 and $3 \mathrm{~min}$, respectively. Further, the estimate for monoterpene contribution to $\mathrm{O}_{3}$ reactivity assumes that all monoterpenes here have the same rate constant as $\alpha$-pinene, as monoterpene measurements were not speciated here and it is one of the more dominant (17 and $45 \%$ by mass) and longer-lived monoterpenes as observed in upwind forested sites by Jardine et al. (2015) and Yáñez-Serrano et al. (2018). As observed concentrations of monoterpenes within canopy are a factor of 3-4 higher than those observed at T3, it is reasonable to expect that $\mathrm{O}_{3}$ loss due to reaction with monoterpenes at this measurement site will become increasingly dominated by reaction with $\alpha$-pinene.

At T3, the observed sesquiterpenes are estimated to have a measurable though smaller contribution $(\sim 10-15 \%)$ to the reactive losses of $\mathrm{O}_{3}$ compared to isoprene $(\sim 40 \%)$ and monoterpenes $(\sim 45 \%)$ for both seasons. The contribution of sesquiterpenes to total $\mathrm{O}_{3}$ loss varies dramatically in space and time, being highest right near the sources of emission. Based on average wind speed $\left(2 \mathrm{~m} \mathrm{~s}^{-1}\right)$, the transport time from the nearest surrounding trees $(1 \mathrm{~km})$ to the measurement site is of the order of at least $8 \mathrm{~min}$, longer than the chemical lifetime of some of the more highly reactive sesquiterpenes. The ozonolysis of sesquiterpenes within the canopy has been estimated to account for about $50 \%$ of sesquiterpene reactivity during the daytime, suggesting significant losses of these compounds before escaping the Amazon forest canopy (Jardine et al., 2011). This is reflected in our measurements of daytime minima being located far from and outside the canopy (Figs. 4a and 5a). This is also evident for monoterpenes, for which concentrations and the associated $\mathrm{O}_{3}$ reactivity at the top of the canopy at an upwind forest site (Jar- 


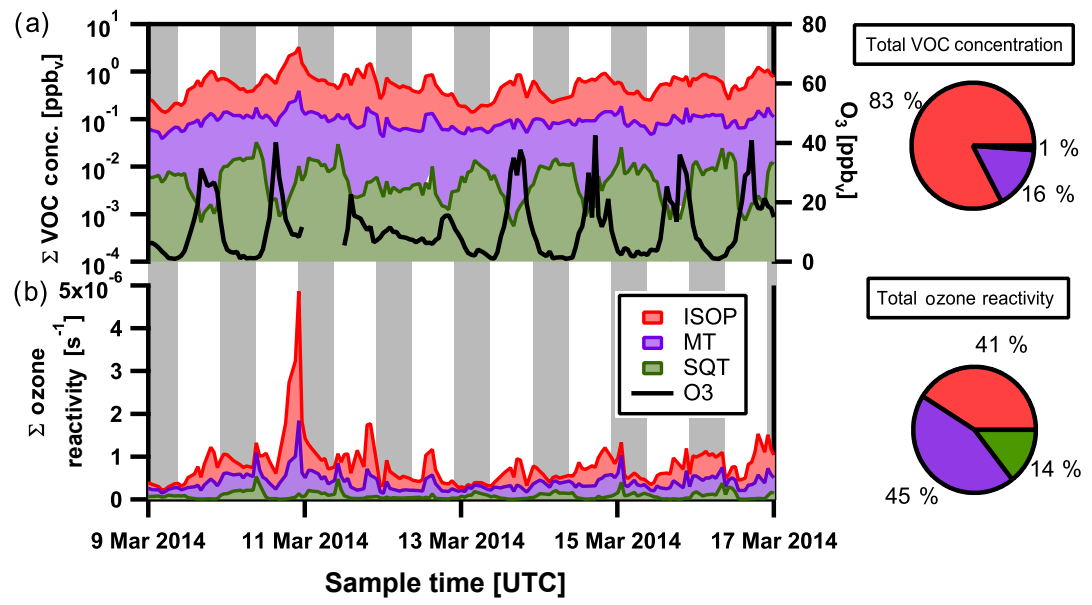

Figure 4. Wet season selected timeline of summed gas-phase VOC concentrations, isoprene (ISOP, red), monoterpenes (MT, purple), and estimated sesquiterpenes (SQTs, green) and ozone concentration $\left(\mathrm{O}_{3}\right.$, black) in panel (a). Average percentage contributions during the wet season for each group to total VOC concentration are also shown in the top pie chart. Panel (b) depicts the summed contribution to ozone reactivity from isoprene, monoterpenes, and sesquiterpenes. Average percentage contributions during the wet season for each VOC to total ozone reactivity are shown in the bottom pie chart. Local nighttime hours indicated in grey. Local time is $-4 \mathrm{~h}$ relative to UTC.

dine et al., 2015) are both approximately 10 times higher than those at the measurement site in this study. Further, the ratio between monoterpene and sesquiterpene concentrations typical within canopy sites upwind during the wet (7.4) and dry (2.4) seasons (Alves et al., 2016) and that observed at our measurement site for both seasons $(\sim 17)$ indicates that the majority of sesquiterpenes have reacted away before our measurement. This is consistent with the fact that lifetimes of all 30 sesquiterpene species detected in SV-TAG with respect to loss via reaction with $\mathrm{O}_{3}$ tend to be $>20$ min, whereas more highly reactive and more commonly studied sesquiterpenes were below detection (Table 1; unobserved or below detection). Hence, sesquiterpene contributions to $\mathrm{O}_{3}$ loss in our study represent a low-end estimate of an undoubtedly important contribution of sesquiterpenes affecting ozone chemistry in the region.

\subsubsection{Differences in chemical composition between sesquiterpene-rich essential oils and ambient samples}

While it is clear that the sesquiterpenes measured at our site represent only a subset of what is emitted from regional vegetation, we further explored the compositional differences between those at our site and those in sesquiterpene-rich copaiba and andiroba essential oils as proxies for sesquiterpene composition at the site of emission. A major difference between the ambient sesquiterpene content (13 February 2014 06:47 UTC, 02:47 LT) and that of the essential oils (Fig. 1, black and red traces, respectively) is the general absence of $\beta$-caryophyllene (Fig. 1, blue label) in ambient samples and its presence in copaiba essential oil (Fig. 1 and Table S3), andiroba oil (Table S3), and previously analyzed essential oils of Amazon origin (Table S4). The chemical reactivity of $\beta$-caryophyllene with $20 \mathrm{ppb}_{\mathrm{v}}$ of ozone typical of polluted conditions from Manaus (Gerken et al., 2016; Trebs et al., 2012) results in a chemical lifetime of 3 min compared to that of $\alpha$-copaene, which is more than $3 \mathrm{~h}$, so any emissions are expected to be quickly depleted through reaction near the emission location. $\beta$-Caryophyllene is detected in ambient samples at our measurement site very rarely, and only when ozone is near zero ppb. This is also expected to be the case with $\alpha$-humulene, which also has a chemical lifetime just under 3 min due to reaction with $\mathrm{O}_{3}$, though it is not as abundant as $\beta$-caryophyllene in copaiba essential oil. Some sesquiterpenes are routinely observed in ambient air that are not in the analyzed copaiba essential oil (e.g., cyperene and $\beta$-gurjunene), which is expected given the rich diversity of plant species in the Amazon that should all have unique terpene contents. The difference in relative abundances of sesquiterpenes in ambient air and the analyzed essential oils (Table S3) also reflects many other variables: additional vegetation with similar sesquiterpene emission profiles, actual emissions relative to tissue content, and chemical fate of the sesquiterpenes once emitted.

Based on the sesquiterpene profile in various essential oils serving as a proxy for sesquiterpene composition upon emission, it becomes clear that the majority of potential $\mathrm{O}_{3}$ reactivity from sesquiterpenes is dominated by $\beta$-caryophyllene ( $>80 \%$ even if only comprising approximately $20 \%$ of total sesquiterpene mass; Table S3). This demonstrates that the estimate of $\mathrm{O}_{3}$ reactivity via reactive loss with sesquiterpenes at our measurement site is a significant underestimate and not representative of near-field $\mathrm{O}_{3}$ chemistry. For example, taking typical terpenoid concentrations within canopy as reported in Alves et al. (2016) and assuming monoterpene and 


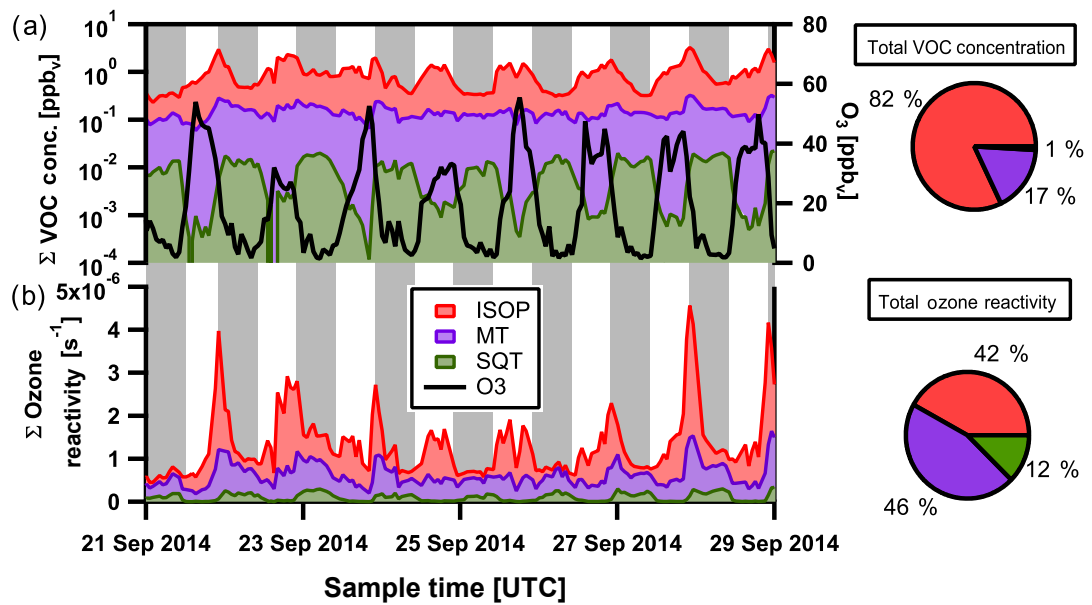

Figure 5. Dry season selected timeline of summed gas-phase VOC concentrations, isoprene (ISOP, red), monoterpenes (MT, purple), and estimated sesquiterpenes (SQTs, green) and ozone concentration $\left(\mathrm{O}_{3}\right.$, black) in panel (a). Average percentage contributions during the dry season for each group to total VOC concentration are also shown in the top pie chart. Panel (b) depicts the summed contribution to ozone reactivity from isoprene, monoterpenes, and sesquiterpenes. Average percentage contributions during the dry season for each VOC to total ozone reactivity are shown in the bottom pie chart. Local nighttime hours indicated in grey. Local time is $-4 \mathrm{~h}$ relative to UTC.

sesquiterpene speciation within canopy to be that of Jardine et al. (2015; for monoterpenes) and that of copaiba essential oil (for sesquiterpenes), near-field or in-canopy loss of $\mathrm{O}_{3}$ is dominated $(>50 \%)$ by reaction with sesquiterpenes for both seasons (Fig. S2). Within the transport time to T3 ( $>8 \mathrm{~min}$ ), the most reactive sesquiterpenes have been reacted away, and the observed contribution to $\mathrm{O}_{3}$ reactivity becomes diminished by a factor of $\sim 5$ for both seasons. This analysis also highlights the importance of using speciated terpene measurements for calculating the oxidative loss of radical species. For example, while the relative contributions to total terpene VOC concentrations are such that isoprene $>$ monoterpenes $>$ sesquiterpenes near the canopy (Fig. S2) and at T3 (Figs. 4a and 5a), the large differences seen in terms of their relative contribution to $\mathrm{O}_{3}$ reactivity at the two locations result from the terpene species prevalent at each site (Figs. S2, 4b, and 5b). In addition, while it is typical practice to take total sesquiterpene concentration and use $k_{\mathrm{O}_{3}+\beta \text {-caryophyllene for all sesquiterpenes (Jardine et al., 2011; }}$; Khan et al., 2017), this would result in an overestimate of sesquiterpene reactivity with $\mathrm{O}_{3}$ by an order of magnitude at T3. Thus, with the majority of sesquiterpene ozonolysis occurring within or just outside the canopy, we expect to observe fewer sesquiterpenes at our measurement site but that their oxidation products may be observed even when the primary sesquiterpenes are not.

\subsubsection{Observation of $\beta$-caryophyllene oxidation products}

$\beta$-Caryophyllene was infrequently observed in ambient samples despite its prevalence in copaiba essential oil, consistent with its rapid reaction with ozone during trans- port from the canopy to the measurement site. However, with SV-TAG we regularly observed $\beta$-caryophyllene oxidation products (specifically $\beta$-caryophyllene aldehyde and $\beta$-caryophyllonic acid) in both the gas and particle phases. These products have maxima at local nighttime hours (Fig. 7) of at most a few $\mathrm{ng} \mathrm{m}^{-3}$ (Fig. S3) and exist predominantly in the gas phase despite previous observations of these products in filter-based measurements (Chan et al., 2011; van Eijck et al., 2013; Jaoui et al., 2003; Li et al., 2011; Winterhalter et al., 2009). Based on saturation vapor pressure estimates for several $\beta$-caryophyllene oxidation products presented in $\mathrm{Li}$ et al. (2011), the gas-phase-only observation of $\beta$-caryophyllene aldehyde (therein referred to as $\mathrm{P}-236$,

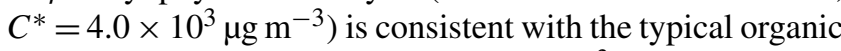
loadings of sampled air at T3 $\left(\sim 1 \mu \mathrm{g} \mathrm{m}^{-3}\right.$ during wet season), though $\beta$-caryophyllonic acid (therein referred to as $\mathrm{P}$ $252-5, C^{*}=8.7 \times 10^{-1} \mu \mathrm{g} \mathrm{m}^{-3}$ ) might be expected to have some contributions to the particle phase.

The speciation of additional oxidation products $\beta$ nocaryophyllonic acid and $\beta$-caryophyllinic acid (typically observed at sub $\mathrm{ng} \mathrm{m}^{-3}$ levels, Fig. S3) was obtained from UHPLC-qToF-MS analysis of selected filters. These products were observed to have daily maxima during local daytime hours (Fig. 7). The differing diel profiles between the four observed $\beta$-caryophyllene oxidation products likely reflects differences in the chemical lifetimes of each product and multiple possible reaction pathways of formation (i.e., $\beta$-caryophyllene initiated oxidation by $\mathrm{O}_{3}$ followed by continued ozonolysis or continued $\mathrm{OH}$ oxidation during daytime). Further, both of these acids are estimated to have atmospheric lifetimes of 2-10 days (Nozière et al., 2015), consistent with the flatter diel profile observed. In addition, be- 

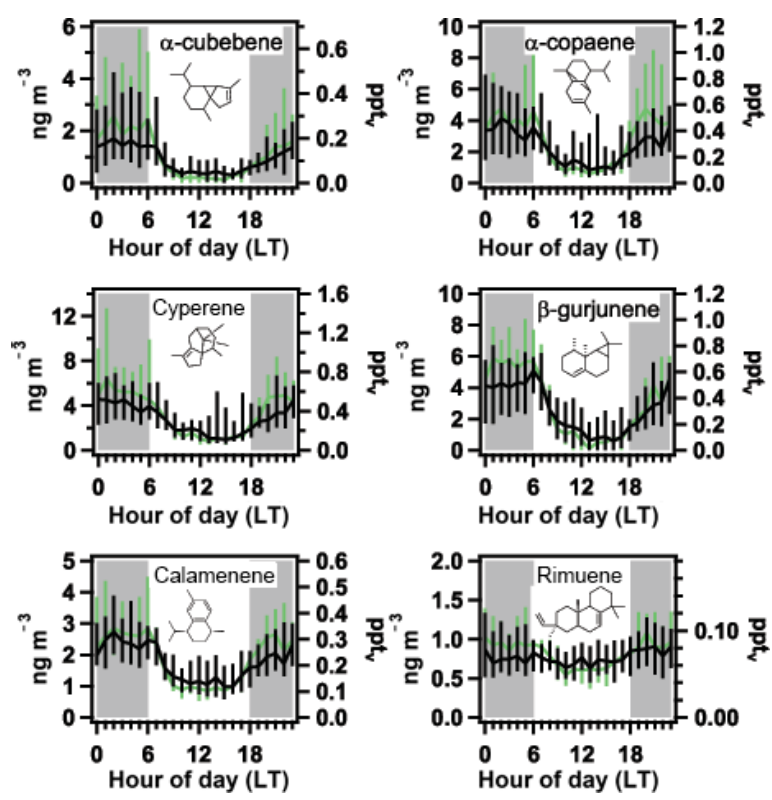

Figure 6. Average diel profiles of selected sesquiterpenes and one diterpene (rimuene) for the wet season (light green) and dry season (black) in gas phase. A solid line is drawn through median values, and bars indicate a range from 25 th to 75 th percentiles. Local nighttime hours are indicated in grey shading.

cause the filter-based measurements have approximately $12 \mathrm{~h}$ time resolution and only a selected period representing significant influence from the Manaus plume was analyzed, the diurnal dynamics of these concentration profiles may not be fully captured.

\subsection{Contribution of sesquiterpene oxidation to secondary organic aerosol}

\subsubsection{Identification and quantification of common terpenoid SOA tracers}

Here, we roughly examine the contribution of isoprene and terpene oxidation to total submicron organic aerosol (OA). Figure 8 shows a selected timeline from the wet season of the total observed OA from the AMS (averaged over the same time frame as our filter samples) and the summed contributions of positively identified molecular tracers from isoprene, monoterpene, and sesquiterpene oxidation. This analysis combines observed tracers from both SV-TAG (particlephase measurements averaged to $12 \mathrm{~h}$ time resolution to match the filter sampling times) and the UHPLC filter-based measurements of monoterpene and sesquiterpene-derived tracers, as listed in Table 2. Estimated contributions to total OA from the oxidation of isoprene have a lower limit of SOA formed through the uptake of isoprene epoxydiol (IEPOX) based on positive matrix factorization (PMF) analysis of AMS data (de Sá et al., 2017). This statistical factor, known as the IEPOX-SOA factor, represents OA mass

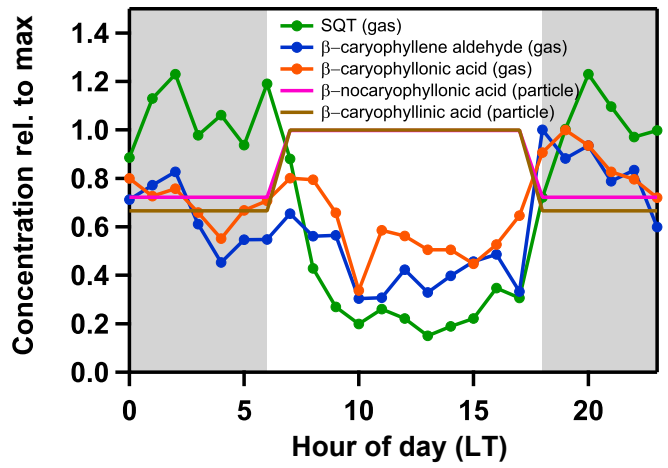

Figure 7. Diel profiles during the wet season of total sesquiterpenes (SQTs) and four $\beta$-caryophyllene oxidation products in gas and particle phases. For each series, data are normalized by the maximum observed concentration within the series and shown as concentration relative to max. Local nighttime hours indicated in grey.

formed from isoprene under sufficiently low $\mathrm{NO}_{x}$ conditions such that IEPOX forms in the gas phase (Paulot et al., 2009), followed by uptake to the particle phase to form SOA (Lin et al., 2012; Liu et al., 2015; Nguyen et al., 2014); it is estimated to account for approximately half of total isoprenederived SOA in environments with low levels of $\mathrm{NO}_{x}$ (Liu et al., 2015). Tracers associated with the IEPOX channel of SOA formation include 2-methyltetrols (2-MTs) observed previously in the Amazon by Claeys et al. (2004) and $\mathrm{C}_{5}$ alkene triols (Surratt et al., 2006b, 2010), both of which are measured by SV-TAG (Isaacman-VanWertz et al., 2016) and correlate well with OA mass attributed to the AMS IEPOXSOA factor (de Sá et al., 2017). For this reason they are presented in Fig. 8 as separate from the remaining IEPOX-SOA factor mass (i.e., IEPOX-SOA factor subtracting SV-TAG measured 2-methyltetrols and $\mathrm{C}_{5}$-alkene triols). In the presence of $\mathrm{NO}_{x}$, there is also production of 2-methylglyceric acid, another tracer of isoprene chemistry (Surratt et al., 2006a) measured at the molecular level by SV-TAG and also presented in Fig. 8. Lower-limit estimates to total OA from the oxidation of monoterpenes (MTs) comprise filter tracers (DTAA, Iinuma et al., 2009; MBTCA, Szmigielski et al., 2007; pinic acid, Yu et al., 1999; pinonic acid, Yu et al., 1999; and terpenylic acid, Claeys et al., 2009). Finally, lower-limit estimates to total OA from the oxidation of sesquiterpenes (SQTs) include the two filter-quantified $\beta$ caryophyllene oxidation products ( $\beta$-nocaryophyllonic acid and $\beta$-caryophyllinic acid). Only approximately $20 \%$ of all OA mass is composed of these identified tracer species and statistical factors, almost all of which $(18 \%)$ is represented by known IEPOX products. However, the yields of known tracer compounds typically represent only a minor fraction of total terpene SOA in laboratory studies: MT acid tracers used here contribute $<10 \%$ of monoterpene SOA (Kristensen et al., 2016), and the SQT acid tracers contribute $<5 \%$ of sesquiterpene SOA (van Eijck et al., 2013; Jaoui et al., 2003). 


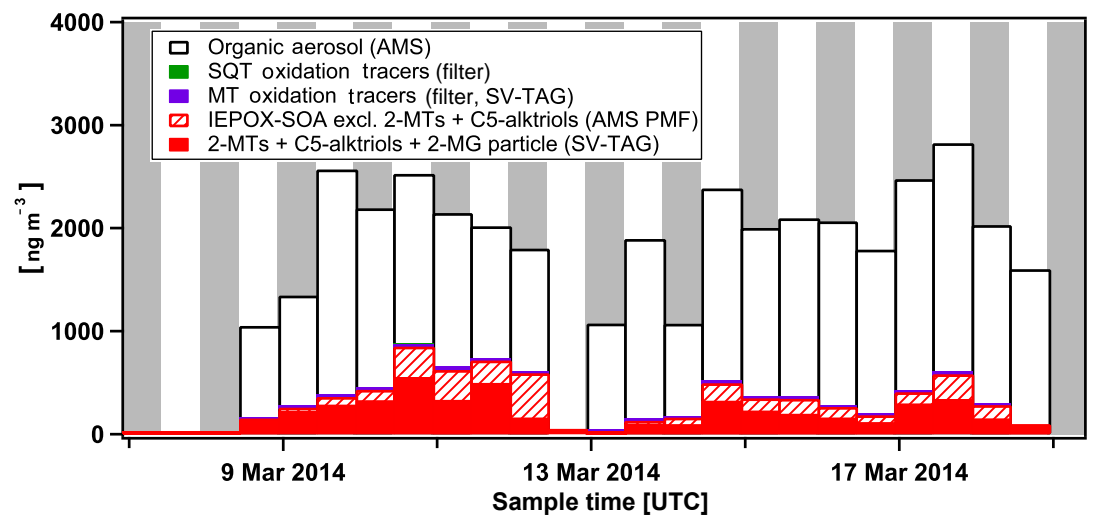

Figure 8. Estimated contributions to total organic aerosol from particle-phase tracers and statistical factors attributed to the oxidation of isoprene (red; IEPOX-SOA, 2-MTs $+\mathrm{C}_{5}$-alktriols $+2-\mathrm{MG}$ ), monoterpene (purple; MT filter tracers), and sesquiterpene (green; SQT filter tracers). 2-MTs: 2-methyl tetrols, 2-MG: 2-methylglyceric acid, $\mathrm{C}_{5}$-alktriols: $\mathrm{C}_{5}$-alkene triols. Local nighttime hours indicated in grey.

Significant work therefore remains for the scientific community to resolve and identify a large fraction of terpene products to understand sources and formation processes. However, these laboratory studies provide an opportunity to estimate the total contribution of monoterpene and sesquiterpene oxidation products to OA using an approximate tracer-based scaling method.

Following the approach of Kleindienst et al. (2007), we take the average summed concentration of $\beta$ nocaryophyllonic acid and $\beta$-caryophyllinic acid $\left(0.15 \mathrm{ng} \mathrm{m}^{-3}\right)$ and scale by their summed product yields (0.045) from the laboratory ozonolysis of $\beta$-caryophyllene (Jaoui et al., 2003). This suggests that the contribution of $\beta$-caryophyllene to typical wet season OA concentrations of $1000 \mathrm{ng} \mathrm{m}^{-3}$ is approximately $0.3 \%$. However, $\beta$-caryophyllene represents only a minor fraction (median: $22 \%$, range $6-83 \%$ ) of the total sesquiterpene content of analyzed essential oil and plant tissues (Table S3). This suggests that the sesquiterpene SOA contribution should be approximately $1 \%$ (range $0.4-5 \%$ ). This is only a rough low-end estimate because (1) it derives from scaling two molecular tracers of $\beta$-caryophyllene oxidation; the actual SOA yield of $\beta$-caryophyllene and other sesquiterpene oxidation is not known under conditions relevant to the Amazon, and yields likely vary as a function of air pollution and other environmental variables. Further, vapor-phase wall losses of the more semi-volatile and lower-volatility oxidation products such as these in environmental chambers may result in non-atmospherically relevant phase partitioning and underestimated product and SOA yields (Krechmer et al., 2016; La et al., 2016; Loza et al., 2010; Matsunaga and Ziemann, 2010; McMurry and Grosjean, 1985; McVay et al., 2014; Ye et al., 2016; Yeh and Ziemann, 2014; Zhang et al., 2014, 2015). (2) This estimate derives from the available analysis of three essential oil types derived from Amazonian tree species: copaiba essential oil (this study; F. Chen et al., 2009; Soares et al., 2013), rosewood essential oil (Fidelis et al., 2012), and andiroba essential oil (this study). While these essential oils typically comprise $\sim 30$ sesquiterpenes, Courtois et al. (2009) report 169 sesquiterpenes emitted by 55 species of tropical trees. Thus, the impact of additional sesquiterpenes reported to be emitted from these plants but not found in the essential oils presented here is unaccounted for. Nevertheless, this estimate demonstrates that sesquiterpene oxidation contributes measurably to SOA based on scaling from specific identified tracers. In addition, previous analysis for the region utilizing PMF during the AMAZE-08 campaign suggests that $50 \%$ of freshly produced secondary organic material may derive from isoprene, $30 \%$ from monoterpenes, and $20 \%$ from sesquiterpenes (Chen et al., 2015). This suggests that a considerable fraction of OA from sesquiterpene oxidation remains to be accounted for through speciated measurements. Considering the chemical diversity of the sesquiterpenes observed here, it would be most ideal to have additional representative tracers and authentic standards to perform a more accurate scaling estimate. While this remains a challenge due to the enormous range of sesquiterpenes and their oxidation products, we provide new tracers and data below.

\subsubsection{Additional identification of terpene oxidation products by mass spectral matching}

It is clear that the majority of oxidation products and SOA mass from $\beta$-caryophyllene and other sesquiterpenes (i.e., beyond $\beta$-nocaryophyllonic acid and $\beta$-caryophyllinic acid) were not identified, and thus a vast array of additional oxidation products must be present. To explore the contributions of additional sesquiterpene oxidation products to $\mathrm{OA}$, non-targeted chemical characterization was performed on selected filters from the wet season that were collected during times when sesquiterpenes were prevalent. The compounds observed in these analyses were uniquely identified by their first- and second-dimension retention times and their mass 
Table 2. Oxidation products from $\beta$-caryophyllene observed in central Amazonia in gas and/or particle phases listed by analysis method. These products are attributed to oxidation from the sesquiterpene (SQTOX) source category. Synthesized standards for tracers $1-6$ were used to confirm identification and for quantification.

\begin{tabular}{|c|c|c|c|c|c|c|c|c|}
\hline No. & Tracer name & Structure & $\begin{array}{l}\text { Source } \\
\text { category }\end{array}$ & Analysis methods & $\begin{array}{l}\text { Chemical } \\
\text { formula }\end{array}$ & $\begin{array}{r}\text { Molecular } \\
\text { weight } \\
\left(\mathrm{g} \mathrm{mol}^{-1}\right)\end{array}$ & $\begin{array}{r}\text { UHRMS } \\
\text { measured } \\
m / z \\
{[\mathrm{M}-1]^{-}}\end{array}$ & $\begin{array}{r}\text { UHRMS } \\
\text { average } \% \\
\text { of total } \\
\text { signal } \\
\text { intensity }\end{array}$ \\
\hline 1 & $\begin{array}{l}\beta \text {-caryophyllene alde- } \\
\text { hyde }\end{array}$ & & SQTOX & $\begin{array}{l}\text { SV-TAG; filter GC } \times \text { GC } \\
\text { HR-ToF-MS; filter ESI- } \\
\text { UHRMS }\end{array}$ & $\mathrm{C}_{15} \mathrm{H}_{24} \mathrm{O}_{2}$ & 236.35 & 235.17023 & 1.2 \\
\hline 2 & $\beta$-caryophyllonic acid & & SQTOX & $\begin{array}{l}\text { SV-TAG; filter GC } \times \text { GC } \\
\text { HR-ToF-MS; filter ESI- } \\
\text { UHRMS }\end{array}$ & $\mathrm{C}_{15} \mathrm{H}_{24} \mathrm{O}_{3}$ & 252.35 & 251.1652 & 0.74 \\
\hline 3 & $\begin{array}{l}\beta \text {-nocaryophyllone alde- } \\
\text { hyde }\end{array}$ & & SQTOX & $\begin{array}{l}\text { Filter GC } \times \text { GC HR-ToF- } \\
\text { MS; filter ESI-UHRMS }\end{array}$ & $\mathrm{C}_{14} \mathrm{H}_{22} \mathrm{O}_{3}$ & 238.32 & 237.14943 & 0.37 \\
\hline 4 & $\beta$-nocaryophyllonic acid & & SQTOX & $\begin{array}{l}\text { Filter UHPLC-MS; filter } \\
\text { ESI-UHRMS }\end{array}$ & $\mathrm{C}_{14} \mathrm{H}_{22} \mathrm{O}_{4}$ & 254.32 & 253.14448 & 0.81 \\
\hline 5 & $\beta$-caryophyllinic acid & & SQTOX & $\begin{array}{l}\text { Filter UHPLC-MS; filter } \\
\text { ESI-UHRMS }\end{array}$ & $\mathrm{C}_{14} \mathrm{H}_{22} \mathrm{O}_{4}$ & 254.32 & 253.14448 & 0.81 \\
\hline 6 & $\beta$-nocaryophyllinic acid & & SQTOX & Filter ESI-UHRMS & $\mathrm{C}_{13} \mathrm{H}_{20} \mathrm{O}_{5}$ & 256.29 & 255.12378 & 0.69 \\
\hline 7 & $\begin{array}{l}\text { DCCA or 3,3-dimethyl- } \\
\text { 2-(3-oxobutyl)- } \\
\text { cyclobutanecarboxylic } \\
\text { acid }\end{array}$ & & SQTOX & Filter ESI-UHRMS & $\mathrm{C}_{11} \mathrm{H}_{18} \mathrm{O}_{3}$ & 198.26 & 197.11828 & 1.25 \\
\hline 8 & $\begin{array}{l}\text { 2-(2-carboxyethyl)- } \\
\text { 3,3-dimethylcyclo- } \\
\text { butanecarboxylic acid }\end{array}$ & & SQTOX & Filter ESI-UHRMS & $\mathrm{C}_{10} \mathrm{H}_{16} \mathrm{O}_{4}$ & 200.23 & 199.09755 & 1.36 \\
\hline
\end{tabular}

spectra. The observed compounds in ambient air samples were compared to the laboratory-generated SOA compounds from sesquiterpene oxidation and a subset of known products from isoprene and monoterpene oxidation.

Figure 9 is a $\mathrm{GC} \times \mathrm{GC}$ chromatogram of a nighttime filter sample taken 12 February 2014 18:30-06:15 LT (22:3010:15 UTC) when sesquiterpenes were relatively abundant. Approximately 460 sample peaks were separated in the chromatogram and their mass spectra and retention indices searched using NIST MS Search via GC Image (Zoex, LLC). A table of the peaks in this sample that could be attributed as BVOC oxidation products, their compound names (if positively identified), and their assigned source category is available in Table S5. The source categories and number of peaks, $n$, assigned to each category in the present analysis include the following: isoprene-derived oxidation products (ISOPOXs, $n=6$ ), monoterpene-derived oxidation products (MTOXs, $n=13$ ), sesquiterpene-derived oxidation products (SQTOXs, $n=41$ ), terpene-derived oxidation products (TERPOXs, $n=10$ ), and other organic aerosol constituents (some not easily categorized) as BVOC oxidation products (other OA, $n=385$ ). The TERPOX category represents compounds that are suspected to derive from monoterpene and/or sesquiterpene oxidation based on MS similarity. 


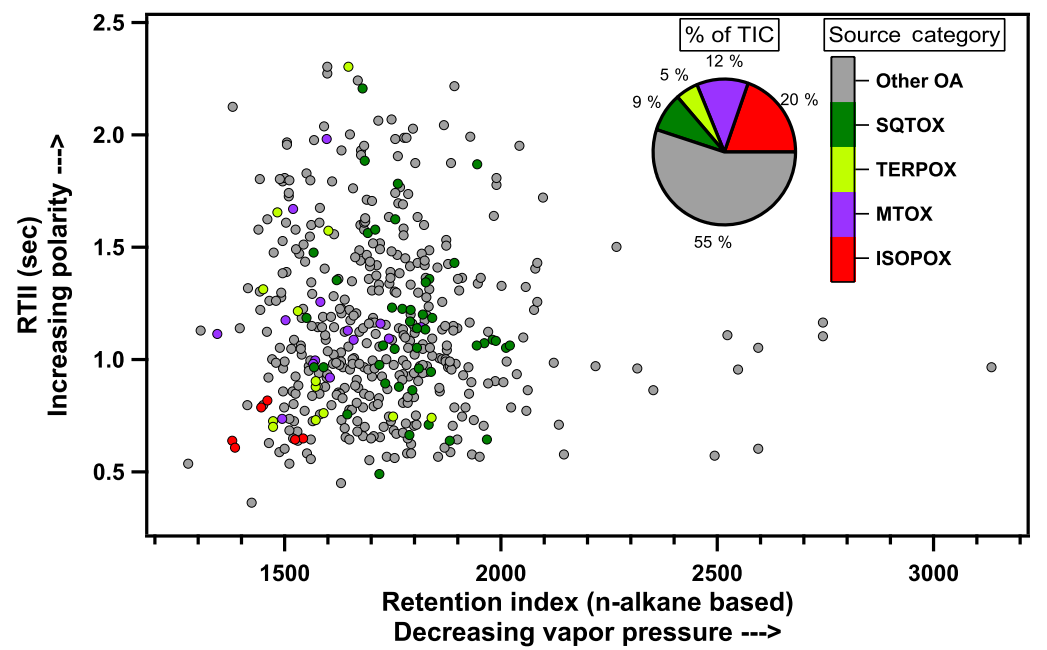

Figure 9. GC $\times$ GC chromatogram of nighttime filter sample during the wet season. Peaks are assigned source categories of isoprene oxidation products (ISOPOXs) in red, monoterpene oxidation products (MTOXs) in purple, terpene oxidation products (TERPOXs) in yellow, and sesquiterpene oxidation products (SQTOXs) in green. Other unidentified OA in grey. The percentage of total ion chromatogram is made up by each source category shown in the pie chart.

That is, good MS matches include oxidation products observed in samples of laboratory monoterpene and sesquiterpene oxidation experiments (some may be overlapping products), but there was no positive delineation between MTOX or SQTOX. Categorized peaks accounted for $45 \%$ of the total signal for this sample, and the rest is labeled other OA.

The pie chart inset in Fig. 9 shows the percentage of the sample signal (total ion chromatogram, TIC, corrected for compound transmission efficiency) associated with each source category. The peaks associated with SQTOX account for $9 \%$ of the corrected TIC, and the peaks associated with TERPOX account for another $5 \%$, at least part of which are likely from sesquiterpene oxidation. This sample highlights the chemical complexity still to be elucidated and quantified in forthcoming analyses of these filter samples to constrain source contributions to total SOA, while demonstrating that numerous unidentified oxidation products derived from sesquiterpenes in this region are present during local nighttime hours. This is consistent with sesquiterpenes dominating ozone reactivity during nighttime hours (Figs. $4 \mathrm{~b}$ and $5 b)$.

\subsubsection{Identification of terpene oxidation products by chemical formulae}

Five filter samples from IOP1 (wet season) during the period 9 February 18:30 LT to 11 February 18:30 LT were analyzed according to procedures described in Sect. 2.3.4 to provide additional insight into the chemical identity (by chemical formula) of sample compounds. The presence of ions with chemical formulae consistent with oxidation products identified in the chromatography-MS methods (SVTAG, GC $\times$ GC-HR-ToF-MS, and UHPLC-MS) provides additional support for their prevalence throughout the wet season and is presented in Table 2 for $\beta$-caryophyllene oxidation products and Table 3 for monoterpene oxidation products. Note that this ESI-UHRMS method is not sensitive to the isoprene oxidation products specified in Table 3 , and thus entries of not applicable (n/a) for the observation of their chemical formulae are used. An average percentage of signal intensity for each UHRMS $m / z$ is also presented for reference, but these should not be directly interpreted as the percentage of total OA. Rather, these are the percentage of sample that this technique is sensitive to, as these samples have complex matrices of organic species that also affect ionization efficiencies.

\section{Conclusion}

We have provided speciated time-resolved measurement of 30 sesquiterpenes and 4 diterpenes and have observed a broad array of sesquiterpene oxidation products in Amazonia, demonstrating that the emitted sesquiterpenes and their oxidation products in this region are both relatively abundant and highly chemically diverse. Most of the observed oxidation products have yet to be fully chemically characterized and quantified, which will be the subject of forthcoming publications. Our observations provide a low-end estimate of the sesquiterpenes in the atmosphere closer to the forest and suggest that sesquiterpene oxidation via ozonolysis is likely the primary reactive fate of these compounds in the region. They exhibit nighttime maxima anticorrelated with ozone and contribute at least $10 \%$ to the reactive loss of $\mathrm{O}_{3}$ compared to that from reaction with isoprene and monoterpenes at our measurement site and $>50 \%$ within or near 
Table 3. Oxidation products from isoprene (ISOPOX) and monoterpenes (MTOXs) in central Amazonia in gas and/or particle phases. Only particle-phase measurement is presented in this study. Products marked not applicable (n/a) are not detected in the UHRMS analysis method.

\begin{tabular}{|c|c|c|c|c|c|c|c|}
\hline No. & Tracer name & $\begin{array}{l}\text { Source } \\
\text { category }\end{array}$ & Analysis methods & $\begin{array}{l}\text { Chemical } \\
\text { formula }\end{array}$ & $\begin{array}{r}\text { Molecular } \\
\text { weight } \\
\left(\mathrm{g} \mathrm{mol}^{-1}\right)\end{array}$ & $\begin{array}{r}\text { UHRMS } \\
\text { measured } m / z \\
m / z[\mathrm{M}-1]^{-}\end{array}$ & $\begin{array}{r}\text { UHRMS } \\
\text { average \% of } \\
\text { total signal } \\
\text { intensity }\end{array}$ \\
\hline 1 & 2-MT 1 or 2-methylerythritol & ISOPOX & $\begin{array}{l}\text { SV-TAG; filter GC } \times \text { GC } \\
\text { HR-ToF-MS }\end{array}$ & $\mathrm{C}_{5} \mathrm{H}_{12} \mathrm{O}_{4}$ & 136.15 & $\mathrm{n} / \mathrm{a}$ & $\mathrm{n} / \mathrm{a}$ \\
\hline 2 & 2-MT 2 or 2-methylthreitol & ISOPOX & $\begin{array}{l}\text { SV-TAG; filter GC } \times \text { GC } \\
\text { HR-ToF-MS }\end{array}$ & $\mathrm{C}_{5} \mathrm{H}_{12} \mathrm{O}_{4}$ & 136.15 & $\mathrm{n} / \mathrm{a}$ & $\mathrm{n} / \mathrm{a}$ \\
\hline 3 & $\begin{array}{l}\mathrm{C}_{5} \text {-alktriol } 1 \text { or } 3 \text {-methyl- } \\
\text { 2,3,4-trihydroxy-1-butene }\end{array}$ & ISOPOX & $\begin{array}{l}\text { SV-TAG; filter } \mathrm{GC} \times \mathrm{GC} \\
\text { HR-ToF-MS }\end{array}$ & $\mathrm{C}_{5} \mathrm{H}_{10} \mathrm{O}_{3}$ & 118.13 & $\mathrm{n} / \mathrm{a}$ & $\mathrm{n} / \mathrm{a}$ \\
\hline 4 & $\begin{array}{l}\mathrm{C}_{5} \text {-alktriol } 2 \text { or cis-2-methyl- } \\
\text { 1,3,4-trihydroxy-1-butene }\end{array}$ & ISOPOX & $\begin{array}{l}\text { SV-TAG; filter } \mathrm{GC} \times \mathrm{GC} \\
\text { HR-ToF-MS }\end{array}$ & $\mathrm{C}_{5} \mathrm{H}_{10} \mathrm{O}_{3}$ & 118.13 & $\mathrm{n} / \mathrm{a}$ & $\mathrm{n} / \mathrm{a}$ \\
\hline 5 & $\begin{array}{l}\text { 2-MGA or 2-methylglyceric } \\
\text { acid }\end{array}$ & ISOPOX & $\begin{array}{l}\text { SV-TAG; filter GC } \times \text { GC } \\
\text { HR-ToF-MS }\end{array}$ & $\mathrm{C}_{4} \mathrm{H}_{8} \mathrm{O}_{4}$ & 120.10 & $\mathrm{n} / \mathrm{a}$ & $\mathrm{n} / \mathrm{a}$ \\
\hline 6 & $\begin{array}{l}\text { DTAA or diaterpenylic acid } \\
\text { acetate }\end{array}$ & MTOX & $\begin{array}{l}\text { Filter UHPLC-MS; filter } \\
\text { ESI-UHRMS }\end{array}$ & $\mathrm{C}_{10} \mathrm{H}_{16} \mathrm{O}_{6}$ & 232.23 & 231.08728 & 0.57 \\
\hline 7 & $\begin{array}{l}\text { MBTCA or 3-methyl-1,2,3- } \\
\text { butanetricarboxylic acid }\end{array}$ & MTOX & $\begin{array}{l}\text { Filter GC } \times \text { GC HR-ToF- } \\
\text { MS; filter UHPLC-MS; } \\
\text { filter ESI-UHRMS }\end{array}$ & $\mathrm{C}_{8} \mathrm{H}_{12} \mathrm{O}_{6}$ & 204.18 & 203.05606 & 0.87 \\
\hline 8 & pinic acid & MTOX & $\begin{array}{l}\text { Filter GC } \times \text { GC HR-ToF- } \\
\text { MS; filter UHPLC-MS; } \\
\text { filter ESI-UHRMS }\end{array}$ & $\mathrm{C}_{9} \mathrm{H}_{14} \mathrm{O}_{4}$ & 186.21 & 185.08186 & 0.96 \\
\hline 9 & pinonic acid & MTOX & $\begin{array}{l}\text { Filter UHPLC-MS; filter } \\
\text { ESI-UHRMS }\end{array}$ & $\mathrm{C}_{10} \mathrm{H}_{16} \mathrm{O}_{3}$ & 184.23 & 183.10259 & 2.73 \\
\hline 10 & terpenylic acid & MTOX & $\begin{array}{l}\text { Filter UHPLC-MS; filter } \\
\text { ESI-UHRMS }\end{array}$ & $\mathrm{C}_{8} \mathrm{H}_{12} \mathrm{O}_{4}$ & 172.18 & 171.06618 & 0.78 \\
\hline 11 & cis-norpinic acid & MTOX & $\begin{array}{l}\text { Filter GC } \times \text { GC HR-ToF- } \\
\text { MS; filter ESI-UHRMS }\end{array}$ & $\mathrm{C}_{9} \mathrm{H}_{16} \mathrm{O}_{3}$ & 172.22 & 171.10252 & 2.97 \\
\hline
\end{tabular}

the canopy. As ozone levels in this region are directly influenced by the outflow of the Manaus plume, we would expect contributions of sesquiterpene-derived SOA to also depend highly on anthropogenic activities. In addition, since ozone enhancements at ground level can result from downdrafts of convective storms, sesquiterpenes are part of an intricate aerosol-oxidant-cloud life cycle. Based on the observation of two $\beta$-caryophyllene oxidation products in aerosols, we estimate that sesquiterpene oxidation contributes at least 0.4 $5 \%$ (median $1 \%$ ) of observed submicron organic aerosol. As the within- or near-canopy reactive loss of sesquiterpenes to $\mathrm{O}_{3}$ is significant, the measurements at $\mathrm{T} 3$ cannot account for the most reactive sesquiterpene species, and their contributions to SOA formation in the region likely remain underestimated by the estimates reported here.

Because several of the observed sesquiterpenes have not been studied in terms of their reaction kinetics with various oxidants (i.e., $\mathrm{O}_{3}, \mathrm{OH}, \mathrm{NO}_{3}$ ) or their oxidative pathways leading to SOA, it is still challenging to fully constrain their role in the atmospheric chemistry of the region. Part of this challenge is stymied by the lack of available authentic standards, so further work in the separation of complex mixtures (e.g., essential oils) to isolate pure sesquiterpenes and chemical synthesis of oxidation products would prove beneficial for furthering our knowledge of sesquiter- pene chemistry. Future fieldwork should focus on performing speciated sesquiterpene measurements within the canopy and connecting the chemical fate and transport from emissions to regional atmospheric chemistry. Further, laboratory oxidation experiments of newly observed sesquiterpenes or relevant mixtures could be used to improve estimates of reactive oxidant loss and contributions to SOA.

Data availability. The datasets used in this publication are available at the ARM Climate Research Facility database for the GoAmazon2014/5 campaign (https://www.arm.gov/research/ campaigns/amf2014goamazon, last access: 1 January 2018). Mass spectra of observed terpene oxidation products are available at https: //nature.berkeley.edu/ahg/data/MSLibrary/ within the file GoAmazon2014_terpox_v1.msp (last access: 23 June 2018).

\section{The Supplement related to this article is available online at https://doi.org/10.5194/acp-18-10433-2018- supplement.}

Author contributions. AG, LM, RdS, AM, PA, JJ, and SM designed, coordinated, and supervised the GoAmazon field campaign and LY, GI, RW, NK, SV, SdS, LA, BB, WH, PC, DD, YL, KM, 
$\mathrm{JV}, \mathrm{MO}$, and KL carried out the measurements and model simulations. $\mathrm{LY}, \mathrm{GI}, \mathrm{MM}, \mathrm{VR}, \mathrm{RW}, \mathrm{SdS}, \mathrm{BB}$, and YL performed data analysis. MB, MG, IK, and MK performed additional analysis of collected filter samples. MA, AB, RT, and FG synthesized and provided chemical standards. JO and ML provided supplementary filter samples from laboratory oxidation experiments to aid data interpretation. LY prepared the paper with contributions from all coauthors.

Competing interests. The authors declare that they have no conflict of interest.

Disclaimer. The EPA has not reviewed this paper, and thus no endorsement should be inferred.

Special issue statement. This article is part of the special issue "Observations and Modeling of the Green Ocean Amazon (GoAmazon2014/5) (ACP/AMT/GI/GMD inter-journal SI)". It is not associated with a conference.

Acknowledgements. The UC Berkeley team was supported for the GoAmazon2014/15 field campaign by NSF ACP grant no. 1332998 and for further analysis of the dataset by DOE ASR grant no. DE-SC0014040. The Northwestern University team was supported by the National Science Foundation (NSF) under grant no. CHE-1607640. The instrument as deployed was developed through support from the U.S. Department of Energy (DOE) SBIR grant DE-SC0004698. We gratefully acknowledge support from the Central Office of the Large-Scale Biosphere-Atmosphere Experiment in Amazonia (LBA), the Instituto Nacional de Pesquisas da Amazonia (INPA), the Universidade do Estado do Amazonia (UEA), and the local foundation FAPEAM. The work was conducted under 001030/2012-4 of the Brazilian National Council for Scientific and Technological Development (CNPq). We acknowledge logistical support from the Atmospheric Radiation Measurement (ARM) Climate Research Facility, a U.S. Department of Energy Office of Science user facility sponsored by the Office of Biological and Environmental Research. ARM-collected data, including ozone and meteorology, were obtained from MAOS. Lindsay D. Yee acknowledges support from a University of California Berkeley Chancellor's Postdoctoral Fellowship. Gabriel Isaacman-VanWertz acknowledges support from an NSF Graduate Research Fellowship (no. DGE 1106400). Brett B. Palm acknowledges support from a U.S. EPA STAR Graduate Fellowship (FP-91761701-0). The University of Colorado group acknowledges support from DOE (BER/ASR) DE-SC0016559 and EPA-STAR 83587701-0. Ariana Gray Bé and Mary Alice Upshur gratefully acknowledge support from NSF Graduate Research Fellowships. Mary Alice Upshur also acknowledges an NSF GROW award, National Aeronautics and Space Administration Earth and Space (NASA ESS) Fellowship, and a P. E. O. Scholar Award. Franz M. Geiger gratefully acknowledges support from the Alexander von Humboldt Foundation.

Edited by: Harald Saathoff

Reviewed by: two anonymous referees

\section{References}

Adams, R. P.: Identification of Essential Oil Components by Gas Chromatography Mass Spectrometry, 4th Edn., Allured Publishing Corporations, Carol Stream, IL, 2007.

Alfarra, M. R., Hamilton, J. F., Wyche, K. P., Good, N., Ward, M. W., Carr, T., Barley, M. H., Monks, P. S., Jenkin, M. E., Lewis, A. C., and McFiggans, G. B.: The effect of photochemical ageing and initial precursor concentration on the composition and hygroscopic properties of $\beta$-caryophyllene secondary organic aerosol, Atmos. Chem. Phys., 12, 6417-6436, https://doi.org/10.5194/acp-12-6417-2012, 2012.

Alves, E. G., Harley, P., Gonçalves, J. F. de C., Moura, C. E. da S., and Jardine, K.: Effects of light and temperature on isoprene emission at different leaf developmental stages of eschweilera coriacea in central Amazon, Acta Amazon, 44, 9-18, https://doi.org/10.1590/S0044-59672014000100002, 2014.

Alves, E. G., Jardine, K., Tota, J., Jardine, A., Yãnez-Serrano, A. M., Karl, T., Tavares, J., Nelson, B., Gu, D., Stavrakou, T., Martin, S., Artaxo, P., Manzi, A., and Guenther, A.: Seasonality of isoprenoid emissions from a primary rainforest in central Amazonia, Atmos. Chem. Phys., 16, 3903-3925, https://doi.org/10.5194/acp-16-3903-2016, 2016.

Artaxo, P., Rizzo, L. V, Brito, J. F., Barbosa, H. M. J., Arana, A., Sena, E. T., Cirino, G. G., Bastos, W., Martin, S. T., and Andreae, M. O.: Atmospheric aerosols in Amazonia and land use change: from natural biogenic to biomass burning conditions, Faraday Discuss., 165, 203-235, https://doi.org/10.1039/C3FD00052D, 2013.

Atkinson, R.: Gas-phase tropospheric chemistry of volatile organic compounds .1. Alkanes and alkenes, J. Phys. Chem. Ref. Data, 26, 215-290, https://doi.org/10.1063/1.556012, 1997.

Atkinson, R. and Arey, J.: Atmospheric Degradation of Volatile Organic Compounds Atmospheric Degradation of Volatile Organic Compounds, Chem. Rev., 103, 4605-4638, https://doi.org/10.1021/cr0206420, 2003.

Bouvier-Brown, N. C., Goldstein, A. H., Gilman, J. B., Kuster, W. C., and de Gouw, J. A.: In-situ ambient quantification of monoterpenes, sesquiterpenes, and related oxygenated compounds during BEARPEX 2007: implications for gas- and particle-phase chemistry, Atmos. Chem. Phys., 9, 5505-5518, https://doi.org/10.5194/acp-9-5505-2009, 2009a.

Bouvier-Brown, N. C., Holzinger, R., Palitzsch, K., and Goldstein, A. H.: Large emissions of sesquiterpenes and methyl chavicol quantified from branch enclosure measurements, Atmos. Environ., 43, 389-401, https://doi.org/10.1016/j.atmosenv.2008.08.039, 2009b.

Bouvier-Brown, N. C., Schade, G. W., Misson, L., Lee, A., Mckay, M., and Goldstein, A. H.: Contributions of biogenic volatile organic compounds to net ecosystem carbon flux in a ponderosa pine plantation, Atmos. Environ., 60, 527-533, https://doi.org/10.1016/j.atmosenv.2012.06.070, 2012.

Bracho-Nuñez, A., Knothe,, N. M., Welter, S., Staudt, M., Costa, W. R., Liberato, M. A. R., Piedade, M. T. F., and Kesselmeier, J.: Leaf level emissions of volatile organic compounds (VOC) from some Amazonian and Mediterranean plants, Biogeosciences, 10, 5855-5873, https://doi.org/10.5194/bg-10-5855-2013, 2013.

Carlton, A. G., Wiedinmyer, C., and Kroll, J. H.: A review of Secondary Organic Aerosol (SOA) formation from isoprene, Atmos. 
Chem. Phys., 9, 4987-5005, https://doi.org/10.5194/acp-9-49872009, 2009.

Chan, A. W. H., Kreisberg, N. M., Hohaus, T., CampuzanoJost, P., Zhao, Y., Day, D. A., Kaser, L., Karl, T., Hansel, A., Teng, A. P., Ruehl, C. R., Sueper, D. T., Jayne, J. T., Worsnop, D. R., Jimenez, J. L., Hering, S. V., and Goldstein, A. H.: Speciated measurements of semivolatile and intermediate volatility organic compounds (S/IVOCs) in a pine forest during BEACHON-RoMBAS 2011, Atmos. Chem. Phys., 16, 11871205, https://doi.org/10.5194/acp-16-1187-2016, 2016.

Chan, M. N., Surratt, J. D., Chan, A. W. H., Schilling, K., Offenberg, J. H., Lewandowski, M., Edney, E. O., Kleindienst, T. E., Jaoui, M., Edgerton, E. S., Tanner, R. L., Shaw, S. L., Zheng, M., Knipping, E. M., and Seinfeld, J. H.: Influence of aerosol acidity on the chemical composition of secondary organic aerosol from $\beta$-caryophyllene, Atmos. Chem. Phys., 11, 1735-1751, https://doi.org/10.5194/acp-11-1735-2011, 2011.

Chen, F., Al-Ahmad, H., Joyce, B., Zhao, N., Köllner, T. G., Degenhardt, J., and Stewart, C. N.: Within-plant distribution and emission of sesquiterpenes from Copaifera officinalis, Plant Physiol. Bioch., 47, 1017-1023, https://doi.org/10.1016/j.plaphy.2009.07.005, 2009.

Chen, Q., Farmer, D. K., Schneider, J., Zorn, S. R., Heald, C. L., Karl, T. G., Guenther, A. B., Allan, J. D., Robinson, N., Coe, H., Kimmel, J. R., Pauliquevis, T., Borrmann, S., Pöschl, U., Andreae, M. O., Artaxo, P., Jimenez, J. L., and Martin, S. T.: Mass spectral characterization of submicron biogenic organic particles in the Amazon Basin, Geophys. Res. Lett., 36, L20806, https://doi.org/10.1029/2009GL039880, 2009.

Chen, Q., Li, Y. L., McKinney, K. A., Kuwata, M., and Martin, S. T.: Particle mass yield from $\beta$-caryophyllene ozonolysis, Atmos. Chem. Phys., 12, 3165-3179, https://doi.org/10.5194/acp12-3165-2012, 2012.

Chen, Q., Farmer, D. K., Rizzo, L. V., Pauliquevis, T., Kuwata, M., Karl, T. G., Guenther, A., Allan, J. D., Coe, H., Andreae, M. O., Pöschl, U., Jimenez, J. L., Artaxo, P., and Martin, S. T.: Submicron particle mass concentrations and sources in the Amazonian wet season (AMAZE-08), Atmos. Chem. Phys., 15, 3687-3701, https://doi.org/10.5194/acp-15-3687-2015, 2015.

Claeys, M., Graham, B., Vas, G., Wang, W., Vermeylen, R., Pashynska, V., Cafmeyer, J., Guyon, P., Andreae, M. O., Artaxo, P., and Maenhaut, W.: Formation of secondary organic aerosols through photooxidation of isoprene, Science, 303, 1173-1176, https://doi.org/10.1126/science.1092805, 2004.

Claeys, M., Iinuma, Y., Szmigielski, R., Surratt, J. D., Blockhuys, F., Van Alsenoy, C., Boge, O., Sierau, B., Gomez-Gonzalez, Y., Vermeylen, R., Van der Veken, P., Shahgholi, M., Chan, A. W. H., Herrmann, H., Seinfeld, J. H., and Maenhaut, W.: Terpenylic Acid and Related Compounds from the Oxidation of $\alpha$-Pinene: Implications for New Particle Formation and Growth above Forests, Environ. Sci. Technol., 43, 6976-6982, https://doi.org/10.1021/es9007596, 2009.

Courtois, E. A., Paine, C. E. T., Blandinieres, P. A., Stien, D., Bessiere, J. M., Houel, E., Baraloto, C., and Chave, J.: Diversity of the volatile organic compounds emitted by 55 species of tropical trees: A survey in French Guiana, J. Chem. Ecol., 35, 1349-1362, https://doi.org/10.1007/s10886-009-9718-1, 2009.

Committee on the Future of Atmospheric Chemistry Research, Board on Atmospheric Sciences and Climate, Division on Earth and Life Studies, National Academies of Sciences, Engineering, and Medicine: The Future of Atmospheric Chemistry Research: Remembering Yesterday, Understanding Today, Anticipating Tomorrow, M. National Academies of Sciences, Engineering, The National Acadamies Press, Washington, D.C., 2016.

Courtois, E. A., Baraloto, C., Timothy Paine, C. E., Petronelli, P., Blandinieres, P. A., Stien, D., Höuel, E., Bessire, J. M., and Chave, J.: Differences in volatile terpene composition between the bark and leaves of tropical tree species, Phytochemistry, 82, 81-88, https://doi.org/10.1016/j.phytochem.2012.07.003, 2012.

DeCarlo, P. F., Kimmel, J. R., Trimborn, A., Northway, M. J., Jayne, J. T., Aiken, A. C., Gonin, M., Fuhrer, K., Horvath, T., Docherty, K. S., Worsnop, D. R., and Jimenez, J. L.: Field-Deployable, High-Resolution, Time-ofFlight Aerosol Mass Spectrometer, Anal. Chem., 78, 8281-8289, https://doi.org/10.1021/ac061249n, 2006.

de Sá, S. S., Palm, B. B., Campuzano-Jost, P., Day, D. A., Newburn, M. K., Hu, W., Isaacman-VanWertz, G., Yee, L. D., Thalman, R., Brito, J., Carbone, S., Artaxo, P., Goldstein, A. H., Manzi, A. O., Souza, R. A. F., Mei, F., Shilling, J. E., Springston, S. R., Wang, J., Surratt, J. D., Alexander, M. L., Jimenez, J. L., and Martin, S. T.: Influence of urban pollution on the production of organic particulate matter from isoprene epoxydiols in central Amazonia, Atmos. Chem. Phys., 17, 6611-6629, https://doi.org/10.5194/acp-17-6611-2017, 2017.

Dommen, J., Metzger, A., Duplissy, J., Kalberer, M., Alfarra, M. R., Gascho, A., Weingartner, E., Prevot, A. S. H., Verheggen, B., and Baltensperger, U.: Laboratory observation of oligomers in the aerosol from isoprene/ $\mathrm{NO}_{x}$ photooxidation, Geophys. Res. Lett., 33, L13805, https://doi.org/10.1029/2006GL026523, 2006.

Dzepina, K., Arey, J., Marr, L. C., Worsnop, D. R., Salcedo, D., Zhang, Q., Onasch, T. B., Molina, L. T., Molina, M. J., Jimenez, J. L., and Jimenez, J. L.: Detection of particle-phase polycyclic aromatic hydrocarbons in Mexico City using an aerosol mass spectrometer, Int. J. Mass Spectrom., 263, 152-170, https://doi.org/10.1016/j.ijms.2007.01.010, 2007.

Fan, J., Rosenfeld, D., Zhang, Y., Giangrande, S. E., Li, Z., Machado, L. A. T., Martin, S. T., Yang, Y., Wang, J., Artaxo, P., Barbosa, H. M. J., Braga, R. C., Comstock, J. M., Feng, Z., Gao, W., Gomes, H. B., Mei, F., Pöhlker, C., Pöhlker, M. L., Pöschl, U., and de Souza, R. A. F.: Substantial convection and precipitation enhancements by ultrafine aerosol particles, Science, 359, 411-418, https://doi.org/10.1126/science.aan8461, 2018.

Fidelis, C. H. V., Augusto, F., Sampaio, P. T. B., Krainovic, P. M., and Barata, L. E. S.: Chemical characterization of rosewood (Aniba rosaeodora Ducke) Leaf Essential Oil By Comprehensive Two-Dimensional Gas Chromatography Coupled With Quadrupole Mass Spectrometry, J. Essent. Oil Res., 24, 245-251, https://doi.org/10.1080/10412905.2012.676770, 2012.

Gerken, T., Wei, D., Chase, R. J., Fuentes, J. D., Schumacher, C., Machado, L. A. T., Andreoli, R. V., Chamecki, M., Ferreira de Souza, R. A., Freire, L. S., Jardine, A. B., Manzi, A. O., Nascimento dos Santos, R. M., von Randow, C., dos Santos Costa, P., Stoy, P. C., Tóta, J., and Trowbridge, A. M.: Downward transport of ozone rich air and implications for atmospheric chemistry in the Amazon rainforest, Atmos. Environ., 124, 64-76, https://doi.org/10.1016/j.atmosenv.2015.11.014, 2016.

Gray Bé, A. G., Upshur, M. A., Liu, P., Martin, S. T., Geiger, F. M., Thomson, R. J., and Paulson, J. A.: Cloud 
Activation Potentials for Atmospheric $\alpha$-Pinene and $\beta$ Caryophyllene Ozonolysis Products, ACS Cent. Sci., 3, 715725, https://doi.org/10.1021/acscentsci.7b00112, 2017.

Griffin, R. J., Cocker, D. R., Seinfeld, J. H., and Dabdub, D.: Estimate of global atmospheric organic aerosol from oxidation of biogenic hydrocarbons, Geophys. Res. Lett., 26, 2721-2724, https://doi.org/10.1029/1999GL900476, 1999a.

Griffin, R. J., Cocker, D. R., Flagan, R. C., and Seinfeld, J. H.: Organic aerosol formation from the oxidation of biogenic hydrocarbons, J. Geophys. Res.-Atmos., 104, 3555-3567, https://doi.org/10.1029/1998JD100049, 1999b.

Guenther, A., Karl, T., Harley, P., Wiedinmyer, C., Palmer, P. I., and Geron, C.: Estimates of global terrestrial isoprene emissions using MEGAN (Model of Emissions of Gases and Aerosols from Nature), Atmos. Chem. Phys., 6, 3181-3210, https://doi.org/10.5194/acp-6-3181-2006, 2006.

Guenther, A. B.: The contribution of reactive carbon emissions from vegetation to the carbon balance of terrestrial ecosystems, Chemosphere, 49, 837-844, https://doi.org/10.1016/S00456535(02)00384-3, 2002.

Guenther, A. B., Jiang, X., Heald, C. L., Sakulyanontvittaya, T., Duhl, T., Emmons, L. K., and Wang, X.: The Model of Emissions of Gases and Aerosols from Nature version 2.1 (MEGAN2.1): an extended and updated framework for modeling biogenic emissions, Geosci. Model Dev., 5, 1471-1492, https://doi.org/10.5194/gmd-5-1471-2012, 2012.

Harley, P., Vasconcellos, P., Vierling, L., Pinheiro, C. C. de S., Greenberg, J., Guenther, A., Klinger, L., Almeida, S. S. de, Neill, D., Baker, T., Phillips, O., and Malhi, Y.: Variation in potential for isoprene emissions among Neotropical forest sites, Glob. Change Biol., 10, 630-650, https://doi.org/10.1111/j.15298817.2003.00760.x, 2004.

Hoffmann, T., Odum, J. R., Bowman, F., Collins, D., Klockow, D., Flagan, R. C., and Seinfeld, J. H.: Formation of organic aerosols from the oxidation of biogenic hydrocarbons, J. Atmos. Chem., 26, 189-222, https://doi.org/10.1023/A:1005734301837, 1997.

Hu, W. W., Campuzano-Jost, P., Palm, B. B., Day, D. A., Ortega, A. M., Hayes, P. L., Krechmer, J. E., Chen, Q., Kuwata, M., Liu, Y. J., de Sá, S. S., McKinney, K., Martin, S. T., Hu, M., Budisulistiorini, S. H., Riva, M., Surratt, J. D., St. Clair, J. M., Isaacman-Van Wertz, G., Yee, L. D., Goldstein, A. H., Carbone, S., Brito, J., Artaxo, P., de Gouw, J. A., Koss, A., Wisthaler, A., Mikoviny, T., Karl, T., Kaser, L., Jud, W., Hansel, A., Docherty, K. S., Alexander, M. L., Robinson, N. H., Coe, H., Allan, J. D., Canagaratna, M. R., Paulot, F., and Jimenez, J. L.: Characterization of a real-time tracer for isoprene epoxydiols-derived secondary organic aerosol (IEPOX-SOA) from aerosol mass spectrometer measurements, Atmos. Chem. Phys., 15, 11807-11833, https://doi.org/10.5194/acp-15-11807-2015, 2015.

Iinuma, Y., Boge, O., Keywood, M., Gnauk, T., and Herrmann, H.: Diaterebic Acid Acetate and Diaterpenylic Acid Acetate: Atmospheric Tracers for Secondary Organic Aerosol Formation from 1,8-Cineole Oxidation, Environ. Sci. Technol., 43, 280285, https://doi.org/10.1021/es802141v, 2009.

Isaacman, G., Kreisberg, N. M., Worton, D. R., Hering, S. V., and Goldstein, A. H.: A versatile and reproducible automatic injection system for liquid standard introduction: application to in-situ calibration, Atmos. Meas. Tech., 4, 1937-1942, https://doi.org/10.5194/amt-4-1937-2011, 2011.
Isaacman, G., Kreisberg, N. M., Yee, L. D., Worton, D. R., Chan, A. W. H., Moss, J. A., Hering, S. V., and Goldstein, A. H.: Online derivatization for hourly measurements of gas- and particlephase semi-volatile oxygenated organic compounds by thermal desorption aerosol gas chromatography (SV-TAG), Atmos. Meas. Tech., 7, 4417-4429, https://doi.org/10.5194/amt-7-44172014, 2014.

Isaacman-VanWertz, G., Yee, L. D., Kreisberg, N. M., Wernis, R., Moss, J. A., Hering, S. V., de Sá, S. S., Martin, S. T., Alexander, M. L., Palm, B. B., Hu, W. W., Campuzano-Jost, P., Day, D. A., Jimenez, J. L., Riva, M., Surratt, J. D., Viegas, J., Manzi, A., Edgerton, E. S., Baumann, K., Souza, R., Artaxo, P., and Goldstein, A. H.: Ambient Gas-Particle Partitioning of Tracers for Biogenic Oxidation, Environ. Sci. Technol., 50, 9952-9962, https://doi.org/10.1021/acs.est.6b01674, 2016.

Jaoui, M., Leungsakul, S., and Kamens, R. M.: Gas and particle products distribution from the reaction of $\beta$ Caryophyllene with ozone, J. Atmos. Chem., 45, 261-287, https://doi.org/10.1023/A:1024263430285, 2003.

Jaoui, M., Sexton, K. G., and Kamens, R. M.: Reaction of $\alpha$-cedrene with ozone: Mechanism, gas and particulate products distribution, Atmos. Environ., 38, 2709-2725, https://doi.org/10.1016/j.atmosenv.2004.02.007, 2004.

Jaoui, M., Kleindienst, T. E., Docherty, K. S., Lewandowski, M., and Offenberg, J. H.: Secondary organic aerosol formation from the oxidation of a series of sesquiterpenes: alpha-cedrene, beta-caryophyllene, alpha-humulene and alpha-farnesene with O-3, $\mathrm{OH}$ and $\mathrm{NO}_{3}$ radicals, Environ. Chem., 10, 178-193, https://doi.org/10.1071/en13025, 2013.

Jaoui, M., Lewandowski, M., Docherty, K. S., Corse, E. W., Lonneman, W. A., Offenberg, J. H., and Kleindienst, T. E.: Photooxidation of farnesene mixtures in the presence of $\mathrm{NO}_{x}$ ?: Analysis of reaction products and their implication to ambient $\mathrm{PM}_{2.5}$, Atmos. Environ., 130, 190-201, https://doi.org/10.1016/j.atmosenv.2015.10.091, 2016.

Jardine, A. B., Jardine, K. J., Fuentes, J. D., Martin, S. T., Martins, G., Durgante, F., Carneiro, V., Higuchi, N., Manzi, A. O., and Chambers, J. Q.: Highly reactive light-dependent monoterpenes in the Amazon, Geophys. Res. Lett., 42, 1576-1583, https://doi.org/10.1002/2014GL062573, 2015.

Jardine, K. J., Yañez Serrano, A., Arneth, A., Abrell, L., Jardine, A. B., Van Haren, J., Artaxo, P., Rizzo, L. V., Ishida, F. Y., Karl, T., Kesselmeier, J., Saleska, S., and Huxman, T.: Within-canopy sesquiterpene ozonolysis in Amazonia, J. Geophys. Res.-Atmos., 116, 1-10, https://doi.org/10.1029/2011JD016243, 2011.

Jardine, K. J., Monson, R. K., Abrell, L., Saleska, S. R., Arneth, A., Jardine, A. B., Ishida, F. Y., Serrano, A. M. Y., Artaxo, P., Karl, T., Fares, S., Goldstein, A., Loreto, F., and Huxman, T.: Within-plant isoprene oxidation confirmed by direct emissions of oxidation products methyl vinyl ketone and methacrolein, Glob. Change Biol., 18, 973-984, https://doi.org/10.1111/j.13652486.2011.02610.x, 2012.

John, W. and Reischl, G.: A Cyclone for Size-Selective Sampling of Ambient Air, JAPCA J. Air. Waste Ma., 30, 872-876, https://doi.org/10.1080/00022470.1980.10465122, 1980.

Jordan, A., Haidacher, S., Hanel, G., Hartungen, E., Märk, L., Seehauser, H., Schottkowsky, R., Sulzer, P., and Märk, T. D.: A high resolution and high sensitivity proton-transfer-reaction time-of-flight mass spectrometer 
(PTR-TOF-MS), Int. J. Mass Spectrom., 286, 122-128, https://doi.org/10.1016/J.IJMS.2009.07.005, 2009.

Kesselmeier, J. and Staudt, M.: Biogenic Volatile Organic Compounds (VOC): An Overview on Emission, Physiology and Ecology, J. Atmos. Chem., 33, 23-88, 1999.

Kesselmeier, J., Guenther, A. B., Hoffmann, T., Piedade, M. T., and Warnke, J.: Natural Volatile Organic Compound Emissions from Plants and their Roles in Oxidant Balance and Particle Formation, in: Amazonia and Global Change, edited by: Keller, P., Bustamante, M., Gash, M., and Silva Dias, J., 183-206, American Geophysical Union, Washington, D.C., 2013.

Khan, M. A. H., Jenkin, M. E., Foulds, A., Derwent, R. G., Percival, C. J., and Shallcross, D. E.: A modeling study of secondary organic aerosol formation from sesquiterpenes using the STOCHEM global chemistry and transport model, J. Geophys. Res.-Atmos., 122, 4426-4439, https://doi.org/10.1002/2016JD026415, 2017.

King, S. M., Rosenoern, T., Shilling, J. E., Chen, Q., Wang, Z., Biskos, G., McKinney, K. A., Pöschl, U., and Martin, S. T.: Cloud droplet activation of mixed organic-sulfate particles produced by the photooxidation of isoprene, Atmos. Chem. Phys., 10, 3953-3964, https://doi.org/10.5194/acp-103953-2010, 2010.

Kleindienst, T. E., Jaoui, M., Lewandowski, M., Offenberg, J. H., Lewis, C. W., Bhave, P. V., and Edney, E. O.: Estimates of the contributions of biogenic and anthropogenic hydrocarbons to secondary organic aerosol at a southeastern US location, Atmos. Environ., 41, 8288-8300, https://doi.org/10.1016/j.atmosenv.2007.06.045, 2007.

Kourtchev, I., Bejan, I., Sodeau, J. R., and Wenger, J. C.: Gasphase reaction of (E)- $\beta$-farnesene with ozone: Rate coefficient and carbonyl products, Atmos. Environ., 43, 3182-3190, https://doi.org/10.1016/J.ATMOSENV.2009.03.048, 2009.

Kourtchev, I., Fuller, S., Aalto, J., Ruuskanen, T. M., Mcleod, M. W., Maenhaut, W., Jones, R., Kulmala, M., and Kalberer, M.: Molecular Composition of Boreal Forest Aerosol from Hyytiälä, Finland, Using Ultrahigh Resolution Mass Spectrometry, Environ. Sci. Technol., 43, 4069-4079, https://doi.org/10.1021/es3051636, 2013.

Kourtchev, I., Fuller, S. J., Giorio, C., Healy, R. M., Wilson, E., O’Connor, I., Wenger, J. C., McLeod, M., Aalto, J., Ruuskanen, T. M., Maenhaut, W., Jones, R., Venables, D. S., Sodeau, J. R., Kulmala, M., and Kalberer, M.: Molecular composition of biogenic secondary organic aerosols using ultrahigh-resolution mass spectrometry: comparing laboratory and field studies, Atmos. Chem. Phys., 14, 2155-2167, https://doi.org/10.5194/acp14-2155-2014, 2014.

Kourtchev, I., Doussin, J.-F., Giorio, C., Mahon, B., Wilson, E. M., Maurin, N., Pangui, E., Venables, D. S., Wenger, J. C., and Kalberer, M.: Molecular composition of fresh and aged secondary organic aerosol from a mixture of biogenic volatile compounds: a high-resolution mass spectrometry study, Atmos. Chem. Phys., 15, 5683-5695, https://doi.org/10.5194/acp-155683-2015, 2015.

Kourtchev, I., Godoi, R. H. M., Connors, S., Levine, J. G., Archibald, A. T., Godoi, A. F. L., Paralovo, S. L., Barbosa, C. G. G., Souza, R. A. F., Manzi, A. O., Seco, R., Sjostedt, S., Park, J.H., Guenther, A., Kim, S., Smith, J., Martin, S. T., and Kalberer, M.: Molecular composition of organic aerosols in central Ama- zonia: an ultra-high-resolution mass spectrometry study, Atmos. Chem. Phys., 16, 11899-11913, https://doi.org/10.5194/acp-1611899-2016, 2016.

Krechmer, J. E., Pagonis, D., Ziemann, P. J., and Jimenez, J. L.: Quantification of Gas-Wall Partitioning in Teflon Environmental Chambers Using Rapid Bursts of Low-Volatility Oxidized Species Generated in Situ, Environ. Sci. Technol., 50, 57575765, https://doi.org/10.1021/acs.est.6b00606, 2016.

Kreisberg, N. M., Hering, S. V., Williams, B. J., Worton, D. R., and Goldstein, A. H.: Quantification of Hourly Speciated Organic Compounds in Atmospheric Aerosols, Measured by an In-Situ Thermal Desorption Aerosol Gas Chromatograph (TAG), Aerosol Sci. Tech., 43, 38-52, https://doi.org/10.1080/02786820802459583, 2009.

Kreisberg, N. M., Worton, D. R., Zhao, Y., Isaacman, G., Goldstein, A. H., and Hering, S. V.: Development of an automated high-temperature valveless injection system for online gas chromatography, Atmos. Meas. Tech., 7, 4431-4444, https://doi.org/10.5194/amt-7-4431-2014, 2014.

Kristensen, K. and Glasius, M.: Organosulfates and oxidation products from biogenic hydrocarbons in fine aerosols from a forest in North West Europe during spring, Atmos. Environ., 45, 45464556, https://doi.org/10.1016/j.atmosenv.2011.05.063, 2011.

Kristensen, K., Watne, A. K., Hammes, J., Lutz, A., Petäjä, T., Hallquist, M., Bilde, M., Glasius, M., Petäjä, T., Hallquist, M., Bilde, M., and Glasius, M.: High-Molecular Weight Dimer Esters Are Major Products in Aerosols from $\alpha$-Pinene Ozonolysis and the Boreal Forest, Environ. Sci. Tech. Let., 3, 280-285, https://doi.org/10.1021/acs.estlett.6b00152, 2016.

Kroll, J. H., Ng, N. L., Murphy, S. M., Flagan, R. C., and Seinfeld, J. H.: Secondary organic aerosol formation from isoprene photooxidation under high- $\mathrm{NO}_{x}$ conditions, Geophys. Res. Lett., 32, 1-4, https://doi.org/10.1029/2005GL023637, 2005.

Kroll, J. H., Ng, N. L., Murphy, S. M., Flagan, R. C., and Seinfeld, J. H.: Secondary Organic Aerosol Formation from Isoprene Photooxidation, Environ. Sci. Technol., 40, 1869-1877, https://doi.org/10.1021/es0524301, 2006.

Kuhn, U.: Isoprene and monoterpene emissions of Amazônian tree species during the wet season: Direct and indirect investigations on controlling environmental functions, J. Geophys. Res., 107, 8071, https://doi.org/10.1029/2001JD000978, 2002.

Kuhn, U., Rottenberger, S., Biesenthal, T., Wolf, A., Schebeske, G., Ciccioli, P., Brancaleoni, E., Frattoni, M., Tavares, T. M., and Kesselmeier, J.: Seasonal differences in isoprene and lightdependent monoterpene emission by Amazonian tree species, Glob. Change Biol., 10, 663-682, https://doi.org/10.1111/j.15298817.2003.00771.x, 2004.

La, Y. S., Camredon, M., Ziemann, P. J., Valorso, R., Matsunaga, A., Lannuque, V., Lee-Taylor, J., Hodzic, A., Madronich, S., and Aumont, B.: Impact of chamber wall loss of gaseous organic compounds on secondary organic aerosol formation: explicit modeling of SOA formation from alkane and alkene oxidation, Atmos. Chem. Phys., 16, 1417-1431, https://doi.org/10.5194/acp16-1417-2016, 2016.

Lee, A., Goldstein, A. H., Keywood, M. D., Gao, S., Varutbangkul, V., Bahreini, R., Ng, N. L., Flagan, R. C., and Seinfeld, J. H.: Gas-phase products and secondary aerosol yields from the ozonolysis of ten different terpenes, J. Geophys. Res., 111, D07302, https://doi.org/10.1029/2005JD006437, 2006a. 
Lee, A., Goldstein, A. H., Kroll, J. H., Ng, N. L., Varutbangkul, V., Flagan, R. C., and Seinfeld, J. H.: Gas-phase products and secondary aerosol yields from the photooxidation of 16 different terpenes, J. Geophys. Res.-Atmos., 111, 1-25, https://doi.org/10.1029/2006JD007050, 2006b.

Lelieveld, J., Butler, T. M., Crowley, J. N., Dillon, T. J., Fischer, H., Ganzeveld, L., Harder, H., Lawrence, M. G., Martinez, M., Taraborrelli, D., and Williams, J.: Atmospheric oxidation capacity sustained by a tropical forest, Nature, 452, 737-740, 2008.

Lelieveld, J., Gromov, S., Pozzer, A., and Taraborrelli, D.: Global tropospheric hydroxyl distribution, budget and reactivity, Atmos. Chem. Phys., 16, 12477-12493, https://doi.org/10.5194/acp-1612477-2016, 2016.

Li, Y. J., Chen, Q., Guzman, M. I., Chan, C. K., and Martin, S. T.: Second-generation products contribute substantially to the particle-phase organic material produced by $\beta$ caryophyllene ozonolysis, Atmos. Chem. Phys., 11, 121-132, https://doi.org/10.5194/acp-11-121-2011, 2011.

Lin, Y.-H., Surratt, J. D., Zhang, Z., Docherty, K. S., Zhang, H., Budisulistiorini, S. H., Rubitschun, C. L., Shaw, S. L., Knipping, E. M., Edgerton, E. S., Kleindienst, T. E., Gold, A., and Surratt, J. D.: Isoprene Epoxydiols as Precursors to Secondary Organic Aerosol Formation: Acid-Catalyzed Reactive Uptake Studies with Authentic Compounds, Environ. Sci. Technol., 46, 250258, https://doi.org/10.1021/es202554c, 2012.

Liu, Y., Kuwata, M., Strick, B. F., Geiger, F. M., Thomson, R. J., McKinney, K. A., and Martin, S. T.: Uptake of Epoxydiol Isomers Accounts for Half of the Particle-Phase Material Produced from Isoprene Photooxidation via the $\mathrm{HO}_{2}$ Pathway, Environ. Sci. Technol., 49, 250-258, https://doi.org/10.1021/es5034298, 2015.

Liu, Y., Brito, J., Dorris, M. R., Rivera-Rios, J. C., Seco, R., Bates, K. H., Artaxo, P., Duvoisin, S., Keutsch, F. N., Kim, S., Goldstein, A. H., Guenther, A. B., Manzi, A. O., Souza, R. A. F., Springston, S. R., Watson, T. B., McKinney, K. A., and Martin, S. T.: Isoprene photochemistry over the Amazon rainforest, P. Natl. Acad. Sci. USA, 113, 6125-6130, https://doi.org/10.1073/pnas.1524136113, 2016.

Loza, C. L., Chan, A. W. H., Galloway, M. M., Keutsch, F. N., Flagan, R. C., and Seinfeld, J. H.: Characterization of Vapor Wall Loss in Laboratory Chambers, Environ. Sci. Technol., 44, 50745078, https://doi.org/10.1021/es100727v, 2010.

Marais, E. A., Jacob, D. J., Jimenez, J. L., Campuzano-Jost, P., Day, D. A., Hu, W., Krechmer, J., Zhu, L., Kim, P. S., Miller, C. C., Fisher, J. A., Travis, K., Yu, K., Hanisco, T. F., Wolfe, G. M., Arkinson, H. L., Pye, H. O. T., Froyd, K. D., Liao, J., and McNeill, V. F.: Aqueous-phase mechanism for secondary organic aerosol formation from isoprene: application to the southeast United States and co-benefit of $\mathrm{SO}_{2}$ emission controls, Atmos. Chem. Phys., 16, 1603-1618, https://doi.org/10.5194/acp16-1603-2016, 2016.

Martin, S. T., Andreae, M. O., Artaxo, P., Baumgardner, D., Chen, Q., Goldstein, A. H., Guenther, A. B., Heald, C. L., MayolBracero, O. L., McMurry, P. H., Pauliquevis, T., Pöschl, U., Prather, K. A., Roberts, G. C., Saleska, S. R., Silva Dias, M. A., Spracklen, D. V., Swietlicki, E., and Trebs, I.: Sources and properties of Amazonian aerosol particles, Rev. Geophys., 48, RG2002, https://doi.org/10.1029/2008RG000280, 2010.
Martin, S. T., Artaxo, P., Machado, L. A. T., Manzi, A. O., Souza, R. A. F., Schumacher, C., Wang, J., Andreae, M. O., Barbosa, H. M. J., Fan, J., Fisch, G., Goldstein, A. H., Guenther, A., Jimenez, J. L., Pöschl, U., Silva Dias, M. A., Smith, J. N., and Wendisch, M.: Introduction: Observations and Modeling of the Green Ocean Amazon (GoAmazon2014/5), Atmos. Chem. Phys., 16, 47854797, https://doi.org/10.5194/acp-16-4785-2016, 2016.

Mather, J. H. and Voyles, J. W.: The arm climate research facility: A review of structure and capabilities, B. Am. Meteorol. Soc., 94, 377-392, https://doi.org/10.1175/BAMS-D-11-00218.1, 2013.

Matsunaga, A. and Ziemann, P. J.: Gas-Wall Partitioning of Organic Compounds in a Teflon Film Chamber and Potential Effects on Reaction Product and Aerosol Yield Measurements, Aerosol Sci. Tech., 44, 881-892, https://doi.org/10.1080/02786826.2010.501044, 2010.

McMurry, P. H. and Grosjean, D.: Gas and Aerosol Wall Losses in Teflon Film Smog Chambers, Environ. Sci. Technol., 19, 11761182, 1985.

McVay, R. C., Cappa, C. D., and Seinfeld, J. H.: Vapor-Wall Deposition in Chambers: Theoretical Considerations, Environ. Sci. Technol., 48, 10251-10258, https://doi.org/10.1021/es502170j, 2014.

Nguyen, T. B., Coggon, M. M., Bates, K. H., Zhang, X., Schwantes, R. H., Schilling, K. A., Loza, C. L., Flagan, R. C., Wennberg, P. O., and Seinfeld, J. H.: Organic aerosol formation from the reactive uptake of isoprene epoxydiols (IEPOX) onto nonacidified inorganic seeds, Atmos. Chem. Phys., 14, 3497-3510, https://doi.org/10.5194/acp-14-3497-2014, 2014.

Nozière, B., Kalberer, M., Claeys, M., Allan, J., D’Anna, B., Decesari, S., Finessi, E., Glasius, M., Grgić, I., Hamilton, J. F., Hoffmann, T., Iinuma, Y., Jaoui, M., Kahnt, A., Kampf, C. J., Kourtchev, I., Maenhaut, W., Marsden, N., Saarikoski, S., Schnelle-Kreis, J., Surratt, J. D., Szidat, S., Szmigielski, R., and Wisthaler, A.: The Molecular Identification of Organic Compounds in the Atmosphere: State of the Art and Challenges, Chem. Rev., 115, 3919-3983, https://doi.org/10.1021/cr5003485, 2015.

Offenberg, J. H., Lewandowski, M., Kleindienst, T. E., Docherty, K. S., Jaoui, M., Krug, J., Riedel, T. P., and Olson, D. A.: Predicting Thermal Behavior of Secondary Organic Aerosols, Environ. Sci. Technol., 51, 9911-9919, https://doi.org/10.1021/acs.est.7b01968, 2017.

Ormeño, E., Gentner, D. R., Fares, S., Karlik, J., Park, J. H., and Goldstein, A. H.: Sesquiterpenoid emissions from agricultural crops: Correlations to monoterpenoid emissions and leaf terpene content, Environ. Sci. Technol., 44, 3758-3764, https://doi.org/10.1021/es903674m, 2010.

Parshintsev, J., Hyötyläinen, T., Hartonen, K., Kulmala, M., and Riekkola, M.-L.: Solid-phase extraction of organic compounds in atmospheric aerosol particles collected with the particle-into-liquid sampler and analysis by liquid chromatography-mass spectrometry, Talanta, 80, 1170-1176, https://doi.org/10.1016/j.talanta.2009.09.004, 2010.

Paulot, F., Crounse, J. D., Kjaergaard, H. G., Kürten, A., St Clair, J. M., Seinfeld, J. H., and Wennberg, P. O.: Unexpected epoxide formation in the gas-phase photooxidation of isoprene, Science, 325, 730-733, https://doi.org/10.1126/science.1172910, 2009. 
Plowden, C.: Production Ecology of Copaiba (Copaifera Spp.) Oleoresin in the Eastern Brazilian Amazon, Econ. Bot., 57, 491-501, 2003.

Pöschl, U., Martin, S. T., Sinha, B., Chen, Q., Gunthe, S. S., Huffman, J. A., Borrmann, S., Farmer, D. K., Garland, R. M., Helas, G., Jimenez, J. L., King, S. M., Manzi, A., Mikhailov, E., Pauliquevis, T., Petters, M. D., Prenni, A. J., Roldin, P., Rose, D., Schneider, J., Su, H., Zorn, S. R., Artaxo, P., and Andreae, M. O.: Rainforest Aerosols as Biogenic Nuclei of Clouds and Precipitation in the Amazon, Science, 329, 15131515, https://doi.org/10.1126/science.1191056, 2010.

Shu, Y. and Atkinson, R.: Rate constants for the gas-phase reactions of $\mathrm{O}_{3}$ with a series of Terpenes and $\mathrm{OH}$ radical formationfrom the $\mathrm{O}_{3}$ reactions with sesquiterpenes at $296 \pm 2 \mathrm{~K}$, Int. J. Chem. Kinet., 26, 1193-1205, https://doi.org/10.1002/kin.550261207, 1994.

Soares, D. C., Portella, N. A., Ramos, M. F. D. S., Siani, A. C., and Saraiva, E. M.: Trans- $\beta$-caryophyllene: An effective antileishmanial compound found in commercial copaiba Oil (Copaifera spp.), Evid.-Based Compl. Alt., 2013, 761323, https://doi.org/10.1155/2013/761323, 2013.

Stein, S. E.: Estimating probabilities of correct identification from results of mass spectral library searches, J. Am. Soc. Mass Spectr., 5, 316-323, https://doi.org/10.1016/10440305(94)85022-4, 1994.

Stein, S. E., Mirokhin, Y., Tchekhovskoi, D., and Mallard, W.: National Institute of Standards and Technology (NIST) Mass Spectral Search Program for the NIST/EPA/NIH Mass Spectral Library, National Institute of Standards and Technology Standard Reference Data Program, Gaithersburg, 2014.

Surratt, J. D., Murphy, S. M., Kroll, J. H., Ng, N. L., Hildebrandt, L., Sorooshian, A., Szmigielski, R., Vermeylen, R., Maenhaut, W., Claeys, M., Flagan, R. C., and Seinfeld, J. H.: Chemical composition of secondary organic aerosol formed from the photooxidation of isoprene, J. Phys. Chem. A, 110, 9665-9690, https://doi.org/10.1021/jp061734m, 2006a.

Surratt, J. D., Murphy, S. M., Kroll, J. H., Ng, N. L., Hildebrandt, L., Sorooshian, A., Szmigielski, R., Vermeylen, R., Maenhaut, W., Claeys, M., Flagan, R. C., and Seinfeld, J. H.: Chemical Composition of Secondary Organic Aerosol Formed from the Photooxidation of Isoprene, J. Phys. Chem. A, 110, 9665-9690, https://doi.org/10.1021/jp061734m, 2006b.

Surratt, J. D., Chan, A. W. H., Eddingsaas, N. C., Chan, M., Loza, C. L., Kwan, A. J., Hersey, S. P., Flagan, R. C., Wennberg, P. O., and Seinfeld, J. H.: Reactive intermediates revealed in secondary organic aerosol formation from isoprene, P. Natl. Acad. Sci. USA, 107, 6640-6645, https://doi.org/10.1073/pnas.0911114107, 2010.

Szmigielski, R., Surratt, J. D., Gómez-González, Y., Van der Veken, P., Kourtchev, I., Vermeylen, R., Blockhuys, F., Jaoui, M., Kleindienst, T. E., Lewandowski, M., Offenberg, J. H., Edney, E. O., Seinfeld, J. H., Maenhaut, W., and Claeys, M.: 3-methyl1,2,3-butanetricarboxylic acid: An atmospheric tracer for terpene secondary organic aerosol, Geophys. Res. Lett., 34, L24811, https://doi.org/10.1029/2007GL031338, 2007.

Thompson, S. L., Yatavelli, R. L. N., Stark, H., Kimmel, J. R., Krechmer, J. E., Day, D. A., Hu, W. W., Isaacman-VanWertz, G., Yee, L., Goldstein, A. H., Khan, M. A. H., Holzinger, R., Kreisberg, N., Lopez-Hilfiker, F. D., Mohr, C., Thornton,
J. A., Jayne, J. T., Canagaratna, M., Worsnop, D. R., and Jimenez, J. L.: Field intercomparison of the gas/particle partitioning of oxygenated organics during the Southern Oxidant and Aerosol Study (SOAS) in 2013, Aerosol Sci. Tech., 51, 30-56, https://doi.org/10.1080/02786826.2016.1254719, 2017.

Trebs, I., Mayol-Bracero, O. L., Pauliquevis, T., Kuhn, U., Sander, R., Ganzeveld, L., Meixner, F. X., Kesselmeier, J., Artaxo, P., and Andreae, M. O.: Impact of the Manaus urban plume on trace gas mixing ratios near the surface in the Amazon Basin: Implications for the $\mathrm{NO}-\mathrm{NO}_{2}-\mathrm{O}_{3}$ photostationary state and peroxy radical levels, J. Geophys. Res.-Atmos., 117, 1-16, https://doi.org/10.1029/2011JD016386, 2012.

U.S. EPA: EPIWeb 4.1, United States Environmental Protection Agency, Washington D.C., USA, 2000.

van Eijck, A., Opatz, T., Taraborrelli, D., Sander, R., and Hoffmann, T.: New tracer compounds for secondary organic aerosol formation from $\beta$-caryophyllene oxidation, Atmos. Environ., 80, 122130, https://doi.org/10.1016/j.atmosenv.2013.07.060, 2013.

Wang, J., Krejci, R., Giangrande, S., Kuang, C., Barbosa, H. M. J., Brito, J., Carbone, S., Chi, X., Comstock, J., Ditas, F., Lavric, J., Manninen, H. E., Mei, F., Moran-Zuloaga, D., Pöhlker, C., Pöhlker, M. L., Saturno, J., Schmid, B., Souza, R. A. F., Springston, S. R., Tomlinson, J. M., Toto, T., Walter, D., Wimmer, D., Smith, J. N., Kulmala, M., Machado, L. A. T., Artaxo, P., Andreae, M. O., Petäjä, T., and Martin, S. T.: Amazon boundary layer aerosol concentration sustained by vertical transport during rainfall, Nature, 539, 416-419, https://doi.org/10.1038/nature19819, 2016.

Williams, B. J., Goldstein, A. H., Kreisberg, N. M., and Hering, S. V.: An In-Situ Instrument for Speciated Organic Composition of Atmospheric Aerosols: Thermal Desorption Aerosol GC/MS-FID (TAG), Aerosol Sci. Tech., 40, 627-638, https://doi.org/10.1080/02786820600754631, 2006.

Winterhalter, R., Herrmann, F., Kanawati, B., Nguyen, T. L., Peeters, J., Vereecken, L., and Moortgat, G. K.: The gasphase ozonolysis of $\beta$-caryophyllene $\left(\mathrm{C}_{15} \mathrm{H}_{24}\right)$. Part I: an experimental study, Phys. Chem. Chem. Phys., 11, 4152, https://doi.org/10.1039/b817824k, 2009.

Worton, D. R., Gentner, D. R., Isaacman, G. A., and Goldstein, A. H.: Embracing Complexity: Deciphering Origins and Transformations of Atmospheric Organics through Speciated Measurements, Environ. Sci. Technol., 46, 5265-5266, https://doi.org/10.1021/es301199y, 2012.

Worton, D. R., Decker, M., Isaacman-Vanwertz, G., Chan, A. W. H., Wilson, K. R., and Goldstein, A. H.: Improved molecular level identification of organic compounds using comprehensive two-dimensional chromatography, dual ionization energies and high resolution mass spectrometry, Analyst, 142, 2395-2403, https://doi.org/10.1039/c7an00625j, 2017.

Xiloteca Calvino Mainieri (BCTw), Herbário Leopoldo Krieger (CESJ), Herbário da Fundação Universidade Federal de Mato Grosso do Sul (CGMS), et al.: The species Link network, available at: http://www.splink.org.br, last access: 3 January 2018.

Xu, L., Kollman, M. S., Song, C., Shilling, J. E., and Ng, N. L.: Effects of $\mathrm{NO}_{x}$ on the volatility of secondary organic aerosol from isoprene photooxidation, Environ. Sci. Technol., 48, 22532262, https://doi.org/10.1021/es404842g, 2014.

Yáñez-Serrano, A. M., Nölscher, A. C., Williams, J., Wolff, S., Alves, E., Martins, G. A., Bourtsoukidis, E., Brito, J., Jardine, K., Artaxo, P., and Kesselmeier, J.: Diel and seasonal changes 
of biogenic volatile organic compounds within and above an Amazonian rainforest, Atmos. Chem. Phys., 15, 3359-3378, https://doi.org/10.5194/acp-15-3359-2015, 2015.

Yáñez-Serrano, A. M., Nölscher, A. C., Bourtsoukidis, E., Gomes Alves, E., Ganzeveld, L., Bonn, B., Wolff, S., Sa, M., Yamasoe, M., Williams, J., Andreae, M. O., and Kesselmeier, J.: Monoterpene chemical speciation in a tropical rainforest:variation with season, height, and time of dayat the Amazon Tall Tower Observatory (ATTO), Atmos. Chem. Phys., 18, 3403-3418, https://doi.org/10.5194/acp-18-3403-2018, 2018.

Ye, P., Ding, X., Hakala, J., Hofbauer, V., Robinson, E. S., and Donahue, N. M.: Vapor wall loss of semi-volatile organic compounds in a Teflon chamber, Aerosol Sci. Tech., 50, 822-834, https://doi.org/10.1080/02786826.2016.1195905, 2016.

Yeh, G. K. and Ziemann, P. J.: Alkyl Nitrate Formation from the Reactions of $\mathrm{C}_{8}-\mathrm{C}_{14} n$-Alkanes with $\mathrm{OH}$ Radicals in the Presence of $\mathrm{NO}_{x}$ : Measured Yields with Essential Corrections for Gas-Wall Partitioning, J. Phys. Chem. A, 118, 8147-8157, https://doi.org/10.1021/jp500631v, 2014.

Yu, J., Cocker III, D. R., Griffin, R. J., Flagan, R. C., and Seinfeld, J. H.: Gas-Phase Ozone Oxidation of Monoterpenes: Gaseous and Particulate Products, J. Atmos. Chem., 34, $207-$ 258, https://doi.org/10.1023/A:1006254930583, 1999.
Zhang, X., Cappa, C. D., Jathar, S. H., McVay, R. C., Ensberg, J. J., Kleeman, M. J., and Seinfeld, J. H.: Influence of vapor wall loss in laboratory chambers on yields of secondary organic aerosol, P. Natl. Acad. Sci. USA, 111, 5802-5807, https://doi.org/10.1073/pnas.1404727111, 2014.

Zhang, X., Schwantes, R. H., McVay, R. C., Lignell, H., Coggon, M. M., Flagan, R. C., and Seinfeld, J. H.: Vapor wall deposition in Teflon chambers, Atmos. Chem. Phys., 15, 4197-4214, https://doi.org/10.5194/acp-15-4197-2015, 2015.

Zhao, Y., Kreisberg, N. M., Worton, D. R., Teng, A. P., Hering, S. V., Goldstein, A. H., and Teng, P.: Development of an In Situ Thermal Desorption Gas Chromatography Instrument for Quantifying Atmospheric Semi-Volatile Organic Compounds Development of an In Situ Thermal Desorption Gas Chromatography Instrument for Quantifying Atmospheric Semi-Volatile Org, Aerosol Sci. Tech., 47, 258-266, https://doi.org/10.1080/02786826.2012.747673, 2013.

Zielinski, A. T., Kourtchev, I., Bortolini, C., Fuller, S. J., Giorio, C., Popoola, O. A. M., Bogialli, S., Tapparo, A., Jones, R. L., and Kalberer, M.: A new processing scheme for ultra-high resolution direct infusion mass spectrometry data, Atmos. Environ., 178, 129-139, https://doi.org/10.1016/j.atmosenv.2018.01.034, 2018. 